\title{
Deconstructing 'The Sense of Place'? Settlement Systems, Field Survey, and the Historic Record: a Case-study from Central Greece
}

\author{
By JOHN BINTLIFF ${ }^{1}$ with assistance from OLIVER DICKINSON ${ }^{2}$, PHIL HOWARD ${ }^{3}$ and ANTHONY SNODGRASS ${ }^{4}$
}

After a generation of intensive regional surface survey in the Mediterranean lands, it is both necessary and enlightening to evaluate the ways in which this new approach has produced results which either support, or demand modifications to, or directly challenge, previous ideas on the evolution of human settlement systems in this macro-region. Given that many regional survey projects have only recently achieved final publication, or are in the final stages of so doing, the implications of these recent discoveries are only now becoming apparent or discussed. The present paper is one attempt to draw wider conclusions from a region of Central Greece - the province of Boeotia, where the author has been conducting intensive survey since 1979. Specifically it compares the state of knowledge regarding the settlement evolution of the region based upon an earlier topographic and extensive survey tradition (Fossey 1988), with the results now available from the author and colleagues' intensive survey in two districts of the province.

A radical reinterpretation of the later prehistoric settlement systems is proposed with significant modifications also to the reconstruction of Classical and Hellenistic settlement networks. Closer agreement with prior knowledge is found with the new information for Roman and Late Roman settlement, whilst the further evolution of regional communities in medieval and post-medieval times - left out of Fossey's Gazetteer - can now be set out in some detail. The latter periods, as a result of highly informative historical sources, especially village tax registers, provide a cautionary tale in the complexities of matching archaeological settlement 'continuities' or 'shifts' with population and ethnic continuity. The overall analysis for the long-term settlement history of the province leads to the suggestion that similarities in settlement patterns have more to do with geography 'constraining and enabling' than with continuities of particular population or ethnic groups. This could seriously undermine the currently fashionable emphasis in Landscape Archaeology on the role of 'memory' and a 'sense of place' in the interpretation of past settlement networks.

Note: The text and ideas of this article are those of John Bintliff. Oliver Dickinson dated the prehistoric ceramics from the Thespiae South/ Leondari South-East survey sector, Phil Howard carried out the GIS and other computer mapping for the same sector and produced the computer diagrams used as illustrations, and finally Anthony Snodgrass has codirected the Boeotia field survey with John Bintliff since its inception in 1978.

${ }^{1}$ Faculteit der Archeologie, Archeologisch Centrum, Postbus 9515, 2300 RA Leiden, Netherlands

${ }^{2}$ Classics Department, Durham University, South Bailey, Durham DH1

${ }^{3}$ Archaeology Department, Durham University, South Road, Durham DH1 3LE

${ }^{4}$ Museum of Classical Archaeology, Cambridge University, Sidgwick Avenue, Cambridge CB3 9DA

Received January 1999. Accepted January 2000.

\section{INTRODUCTION: THE SYNTHESIS OF J.M. FOSSEY}

In any discussion of the development of prehistoric and historic settlement in Boeotia (Fig. 1), the masterly two-volume monograph of Professor John Fossey (1988) is the natural, if not the only starting point. It offers an excellent survey of the published material by the mid-1980s, and also provides a useful basis for propositions regarding settlement dynamics testable by further more intensive landscape research.

Figure 2 and Table 1 summarise the overall settlement history, firstly Fossey's own histogram of changing site numbers (Fig. 2), then my own analysis and summary of his data (including trends partly identified by Fossey himself) (Table 1). Fossey suggested that there appeared to be a broad level of 
THE PREHISTORIC SOCIETY

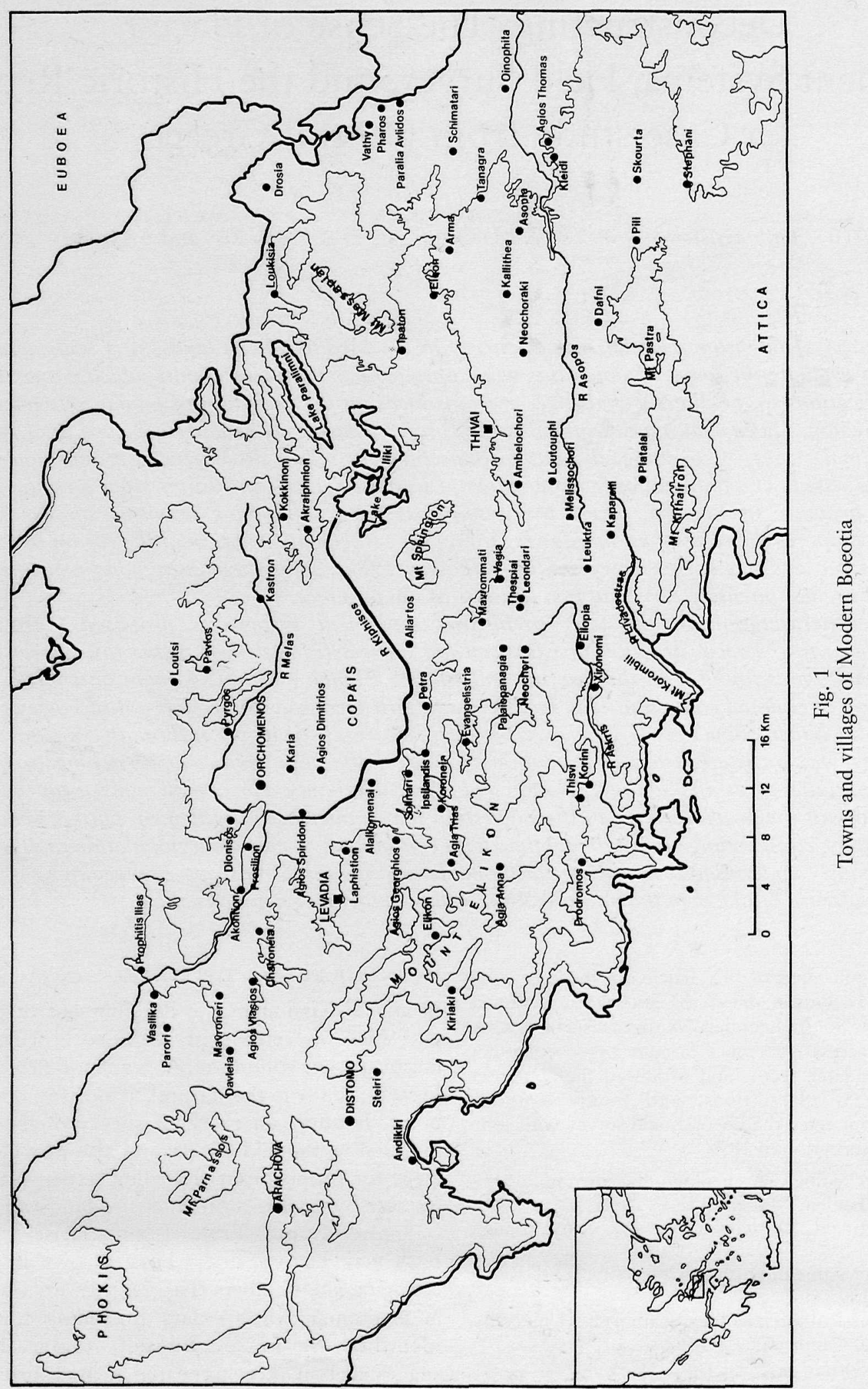


6. J. Bintcliff et al. DECONSTRUCTING 'THE SENSE OF PLACE'? SETTLEMENT, FIELD SURVEY, HIST REC: CENT GREECE

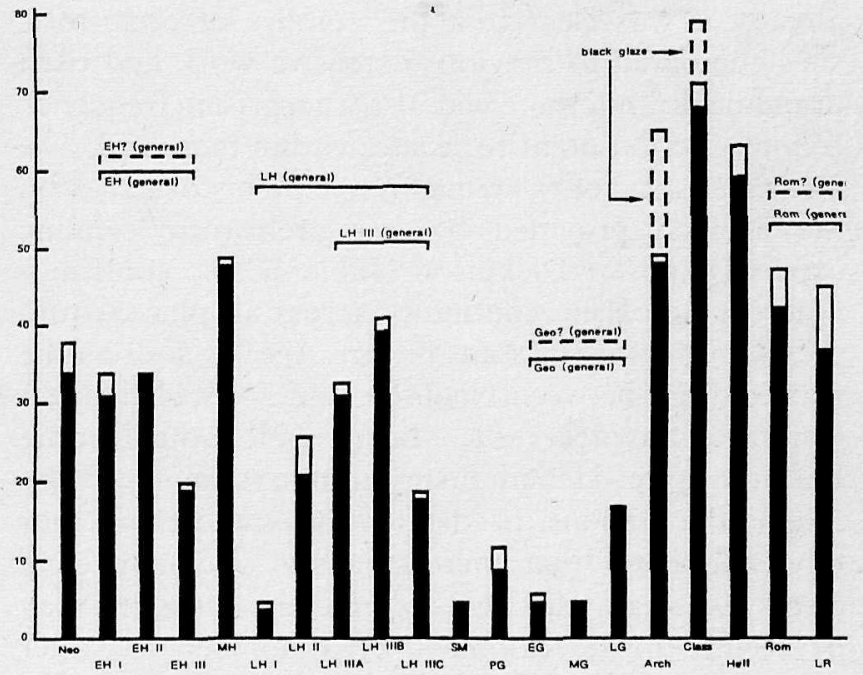

Fig. 2

Histogram of Boeotian sites in Fossey's Gazetteer (1988)

continuity in site occupation through the later prehistoric farming eras (Neolithic to Late Bronze Age), and on to Greco-Roman times, with however the occasional significant site loss - perhaps to be associated with the arrival of new populations (for example at the end of the Early Bronze Age [EH], and also over the period from the end of the Late Bronze age $[\mathrm{LH}]$ into the Early Iron Age [Dark Age]. Also there took place notable expansions of population and settlement numbers (for example, from Neolithic to Early Helladic, from Middle Helladic to Late Helladic, during Archaic-Classical times and in the Late Roman era). Nonetheless Fossey suggested that the basis for the Early Modern village pattern (Fig. 1) was already anticipated in the main lines of the mature Greco-Roman settlement network. His spatial analysis identified an underlying long-term settlement structure with key cities at $14 \mathrm{~km}$ radius catchment, lesser communities at $3 \mathrm{~km}$ radius.

THE BOEOTIA PROJECT INTENSIVE SURVEY

The settlement data synthesised and in large part also collected by John Fossey for Boeotia were overwhelmingly the result of 'extensive' topographic research in the Boeotian landscape. More recently a new tradition of field-by-field inspection of the land surface for past settlements has become normal in many regions of Greece. This type of 'intensive' survey has been applied in several Boeotian districts (Fig. 1), for example in the district of modern Prodromos (formerly Khostia) village near the south coast by Professor Fossey's team, in the Skourta Plain in the far south-east of the region by Mark Munn and his team, and by the Durham-Cambridge Boeotia Project (codirected by myself and Anthony Snodgrass), which has carried out intensive surface survey in two districts of the province - South-Central Boeotia around the ancient cities of Thespiae and Haliartos (adjacent to the modern communities of Thespiai and Aliartos), and North-Central Boeotia around ancient Hyettos city (lying between the modern villages of Loutsi and Pavlos) (Bintliff \& Snodgrass 1985; 1988a; Bintliff 1991; 1992).

In this paper I present preliminary results on these longer-term settlement issues from the DurhamCambridge Boeotia Project. This Project has currently

TABLE 1: ANALYSIS OF J.M. FOSSEY BOEOTIA SITE GAZETTEER (1988)

\begin{tabular}{lccc}
\hline Phase & No. Sites & Continuity to next phase & New sites added in next phase \\
\hline Neolithic & 34 & 29 \\
Early Helladic & 60 & (Notable site number expansion) \\
$\begin{array}{l}\text { Middle Helladic } \\
\text { Late Helladic }\end{array}$ & 48 & 45 & 31 \\
Late Geometric & c. 60 & (Notable site number contraction then expansion) \\
+generic Geometric & $35-40$ & (Strong linkage to LH locations) \\
Archaic & 47 & (Strong linkage to LH locations) \\
Classical & 74 & (Notable site number expansion) \\
Roman-Late Roman & $40-60$ & (Almost all Classical-Hellenistic locations, and 3/4 Early Roman go on to Late Roman) \\
\hline
\end{tabular}

By mid-1980s c. 97 sites documented for the period from Prehistoric to Late Roman 
completed all its fieldwork and the results of almost 20 years' field research are now in process of detailed interpretation for publication. At this point it is very appropriate to remark that our Project has benefitted enormously in recent years from the wholehearted support of the Ephor for Boeotian Antiquities - Dr Vassilis Aravantinos - a degree of assistance and encouragement which deserves a very public acknowledgement.

The total area surveyed by our Project with almost $100 \%$ spatial cover (fieldwalkers normally at $15 \mathrm{~m}$ intervals) is just over $50 \mathrm{~km}^{2}$. With the advantage of a new, far more intensive level of land surface research, it is worthwhile to examine the statistics of the Boeotia Project's two 'windows' into the Boeotian prehistoric and historic landscape, and compare them with John Fossey's essentially extensive settlement database compiled during the mid-1980s (Table 2).

We can begin by observing the expected dramatic rise in site recognition (a factor of 90) through focused, almost $100 \%$, fieldwalking. It is also noteworthy that the increase is predominantly made up of smaller rural sites of the Greek and Roman eras, ie, farms, villas, and hamlets, secondarily in quantity through medieval and post-medieval rural sites of similar character. The increase in prehistoric sites is very important but numerically far less striking (a factor of 22).

\section{PRELIMINARY OBSERVATIONS ON OUR RESULTS}

\section{Prehistoric}

In 1985 we published a preliminary report on the site numbers being recovered up to that point from the Boeotia Project survey (Bintliff \& Snodgrass 1985): already it was clear that the number of prehistoric sites compared to previous extensive work had risen dramatically, but there was also a surprising frequency of multi-period prehistoric sites within that total. The latest statistics for the recognisable prehistoric sites on the Project, provided by our prehistoric ceramic expert Dr Oliver Dickinson (Table 3) also confirm a high degree of site continuity across all phases from the Neolithic to the Late Bronze Age, as well as the expected rise between Neolithic and Early Helladic, a general balance of Early Helladic-Middle Helladic-Late Helladic site numbers nuanced by minor fluctuations in detail, and indications (not tabulated here) that increasing site size may be a trend. Especially during Late Helladic times we may be seeing the development of a number of larger village foci (such as the site of VM4 in the Valley of the Muses, west of the village of Palaiopanagia; Fig. 1 ), hinting at an greater overall population in Mycenaean times than at any era previously. But nonetheless the picture emerging is one of a rather stable network of long-lived rural settlements across the entire Bronze Age, with perhaps the typical prehistoric site of the earlier Fossey Gazetteer now appearing as one of a series of larger rural village foci, around which the newly-documented, and far more numerous, smaller farm/hamlet sites rise and fall in frequency - as revealed by intensive survey, but with little dramatic relocation or rise and decline of the network of settlement foci for both size levels.

Despite this seemingly satisfactory expansion of our knowledge of prehistoric settlement systems in Boeotia, I have been increasingly aware of disturbing anomalies in our understanding of the taphonomy and surface character of prehistoric sites. A striking and well-documented example will serve to illustrate the

TABLE 2: DURHAM-CAMBRIDGE BOEOTIA PROJECT: INCREASE IN SITE DENSITY USING INTENSIVE, FIELD-BY-FIELD SURFACE SURVEY

\begin{tabular}{|c|c|c|}
\hline & $\begin{array}{l}\text { Fossey } 1988^{1} \\
\text { (ancient Boeotia }=2500 \mathrm{sq} \mathrm{km} \text { ) }\end{array}$ & $\begin{array}{l}\text { Boeotia Project }(1978-98)^{2} \\
(2 \text { blocs, total area c. } 50 \mathrm{sq} \mathrm{km})\end{array}$ \\
\hline Total No. sites & 97 & $>200$ sites \\
\hline Sites per sq km & \multicolumn{2}{|c|}{ multiplier for site increase, all periods, using intensive survey $=x 90$} \\
\hline Prehistoric site density: & c. 75 & c. 31 \\
\hline Sites per sq km & \multicolumn{2}{|c|}{ multiplier for prehistoric site increase, using intensive survey $=x 22$} \\
\hline
\end{tabular}

${ }^{1}$ Essentially extensive survey knowledge

${ }^{2}$ Total intensive survey knowledge 
6. J. Bintcliff et al. DECONSTRUCTING 'THE SENSE OF PLACE'? SETTLEMENT, FIELD SURVEY, HIST REC: CENT GREECE TABLE 3: BOEOTIA SURVEY PROJECT (1978-98): PREHISTORIC 'SITE' STATISTICS FOR C. 50 SQ KM INTENSIVELY FIELDWALKED

\begin{tabular}{lccc}
\hline Phase & No. Sites & Continuity to next period & New sites added in next phase \\
\hline Neolithic & 6 & 6 & 22 \\
Early Helladic & 28 & (Notable site number expansion) & 1 \\
Middle Helladic & 22 & 21 & 3 \\
Late Helladic & 25 & - & - \\
\hline
\end{tabular}

(Dr O.T.P.K. Dickinson, pers. comm.)

problem. A small ancient farm-site in the Valley of the Muses, site VM2, stood out as a clear rise in surface ceramic density during fieldwalking. As is customary, the locality was returned to, and gridded intensive counting at, and collection from, the site were undertaken (Fig. 3), revealing a particular accumulation of surface finds in the east of the site grid. The dated sample was dominated by Classical Greek material (Fig. 4) and pointed to a small 'family farm' type of establishment of a fraction of a hectare in scale, probably a single farmhouse lying in the east of the grid, to be associated with a yard and outbuildings/gardens occupying the remainder of the site to the west. However, amongst the sample of dated finds a much smaller complement of Late Bronze Age sherds came to light, focused on the central part of the

\section{Site VM2 - Raw Sherd Counts}

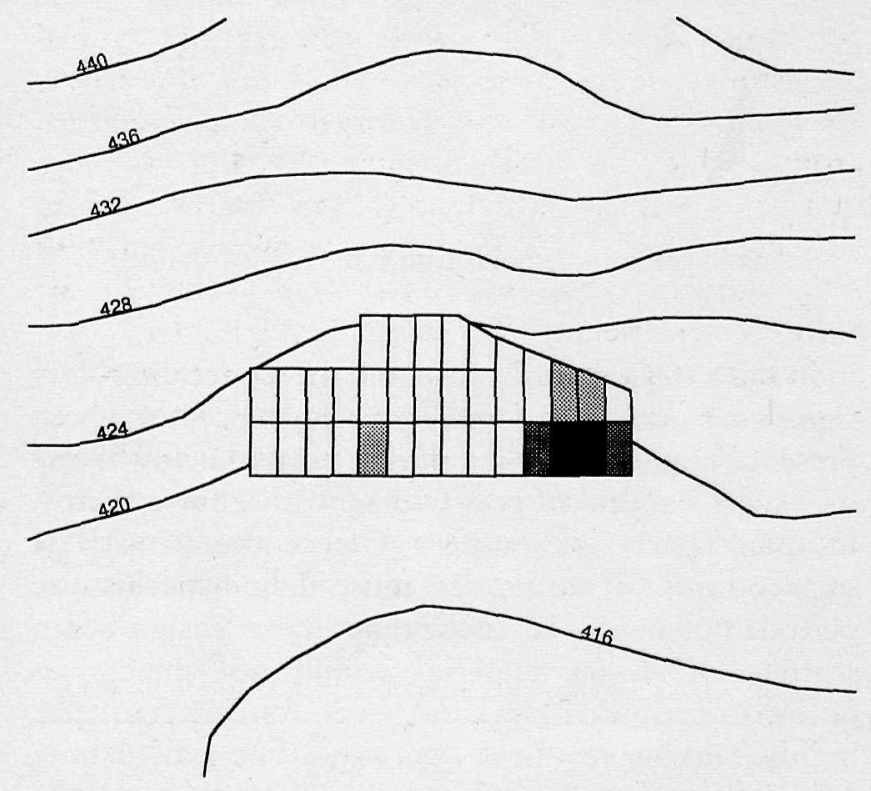

Sherd Density Trends

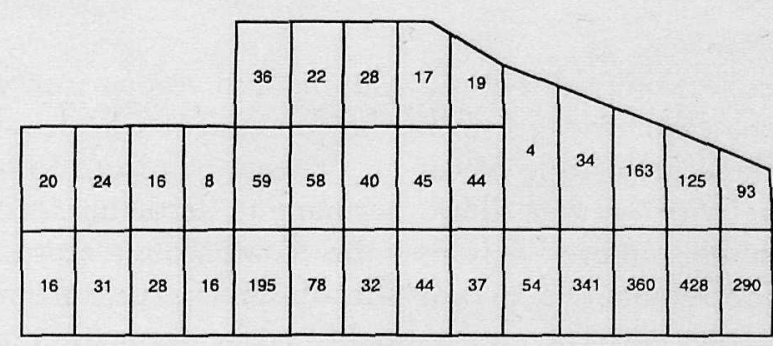

Raw Sherd Counts

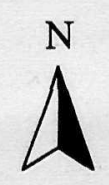

Fig. 3

Site VM2, Boeotia Survey, count of sherd density across the site grid, not corrected for visibility.

Grid based on units of $7.5 \times 10 \mathrm{~m}$ 


\section{Site VM2 (a-eh)}
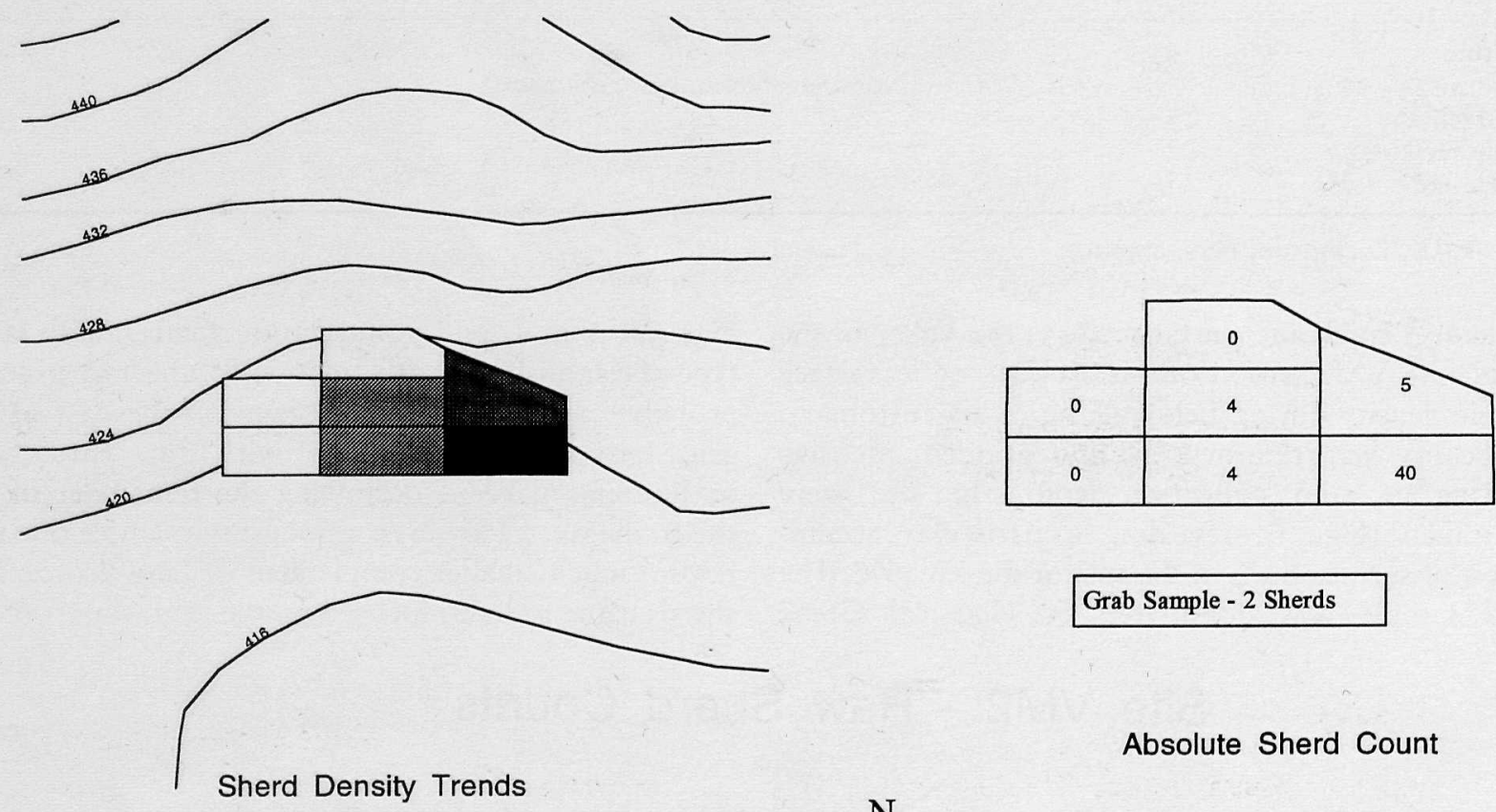

Grab Sample - 2 Sherds

\section{Absolute Sherd Count}

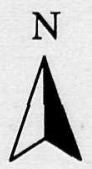

Fig. 4

Site VM2, Boeotia Survey, distribution of Classical Greek sherds in the sample collection removed for dating

collection grid (Fig. 5). Although, in comparison with the clear evidence from the subsequent Classical era, these prehistoric pieces might seem to record 'off-site activity' rather than permanent settlement, it is actually more likely that this small scatter represents the remnant of a farm-site of similar scale from an earlier era. The poorer quality of the dominant coarse and domestic ware, coupled with a far longer period of weathering by cultivation and climate, and the further destructive effect of disturbance and destruction from reuse of the site area, have all acted to reduce the quantity of prehistoric finds compared to those of the Classical era. Thus we would argue that the presentday contrast in surface evidence exposed in Figures 4 and 5 could be taken as a symptomatic one for sites of similar original character but greatly differing age and taphonomic history.

Since finds of the Middle and Early Brònze Age are even more dominated by coarser wares, poorly surviving in the ploughsoil, we began to be convinced that the Greek landscape could be concealing very significant numbers of smaller prehistoric sites whose presence might be marked during normal fieldwalking by a mere handful of poorly-diagnostic coarse sherds. In many parts of southern Greece the density of surface finds of the harder, more diagnostic historic period potsherds is such that these insignificant scatters of earlier material would not qualify as noteworthy potential sites, even during modern, highly intensive field survey. The disturbing implication of these considerations was that, despite the remarkable increase in the number of prehistoric 'sites' documented in Oliver Dickinson's latest analysis of the Boeotia Project site database, compared to the earlier Fossey catalogue, our intensive survey would, for the most part, identify only the larger prehistoric settlements, or those with the longest use, as 'sites'. Recognition of historic sites, followed by their gridded collection, as at VM2, would purely by chance provide an opportunity to 


\section{Site VM2 (LH)}
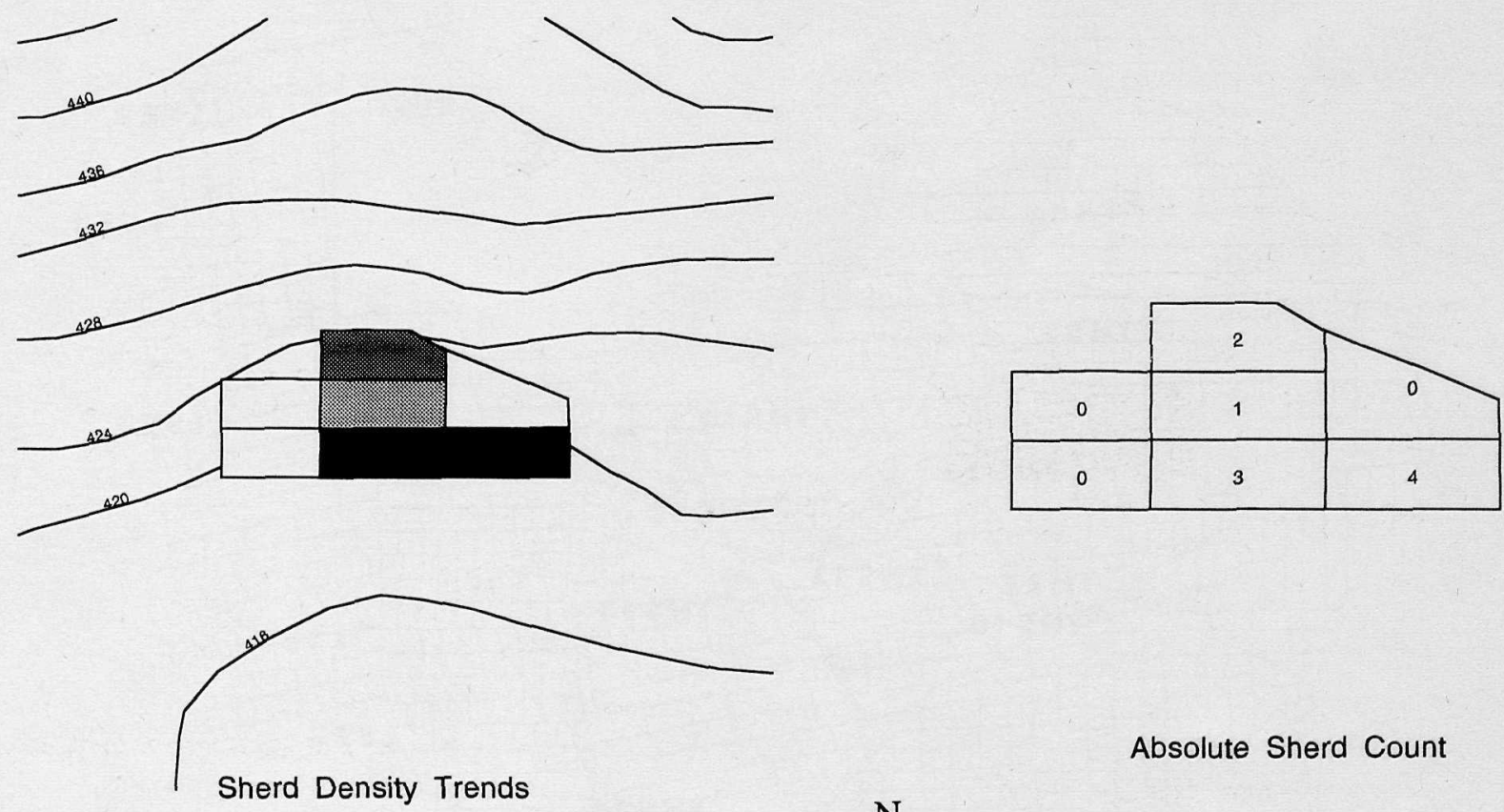

Absolute Sherd Count

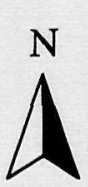

Fig. 5

Site VM2, Boeotia Survey, distribution of Late Bronze Age sherds in the sample collection removed for dating

'hoover' parts of the landscape in such a way as to bring to light those additional, seemingly insignificant, handfuls of prehistoric material in other localities. These accidental findspots would, however, generally be assigned to 'off-site scatter' status and not be included in the 'site' catalogue.

The preparation of the first district of the Boeotia Project survey for final publication, a zone south of ancient Thespiae city known as the LSE/THS sector (immediately south of the modern villages of Thespiai and Leondari on Figure 1) has allowed us to test the implications of this new model of the 'secret - landscape' of prehistoric southern Greece. This area was totally fieldwalked, over a surface of $5.2 \mathrm{~km}^{2}$, with 18 'sites' being recognised and gridded for heightened study and collection (in fact, one was subsequently confirmed as a 'non-site') (Fig. 6). All the sites identified were of historic age - Classical Greek and Roman sites of small-to-medium size and one larger rural settlement of Late Roman and medieval age. None of the 17 confirmed sites showed 'significant' amounts of prehistoric ceramic or lithic to compare with the rich finds of historic age which led to these sites being distinguished from local 'background' scatters of surface pottery. The area is in fact particularly rich in surface pottery (even for lowland Boeotia), and this can be demonstrated through Figures $7 a$ and $7 b$, which display the density of surface ceramics (by transect, per hectare, corrected for surface visibility variations) across the entire 5.2 $\mathrm{km}^{2}$ fieldwalked, together with the location of the giant survey grid used for the surface study of the city of Thespiae immediately to the north. An average density of 2635 sherds per hectare was recorded (corrected for ground visibility), with a total reconstructed density for the district of over 1.37 million surface sherds.

The explanation for such remarkable quantities across the entire landsurface can only be the ancient practice of manuring, essentially carried out by the 


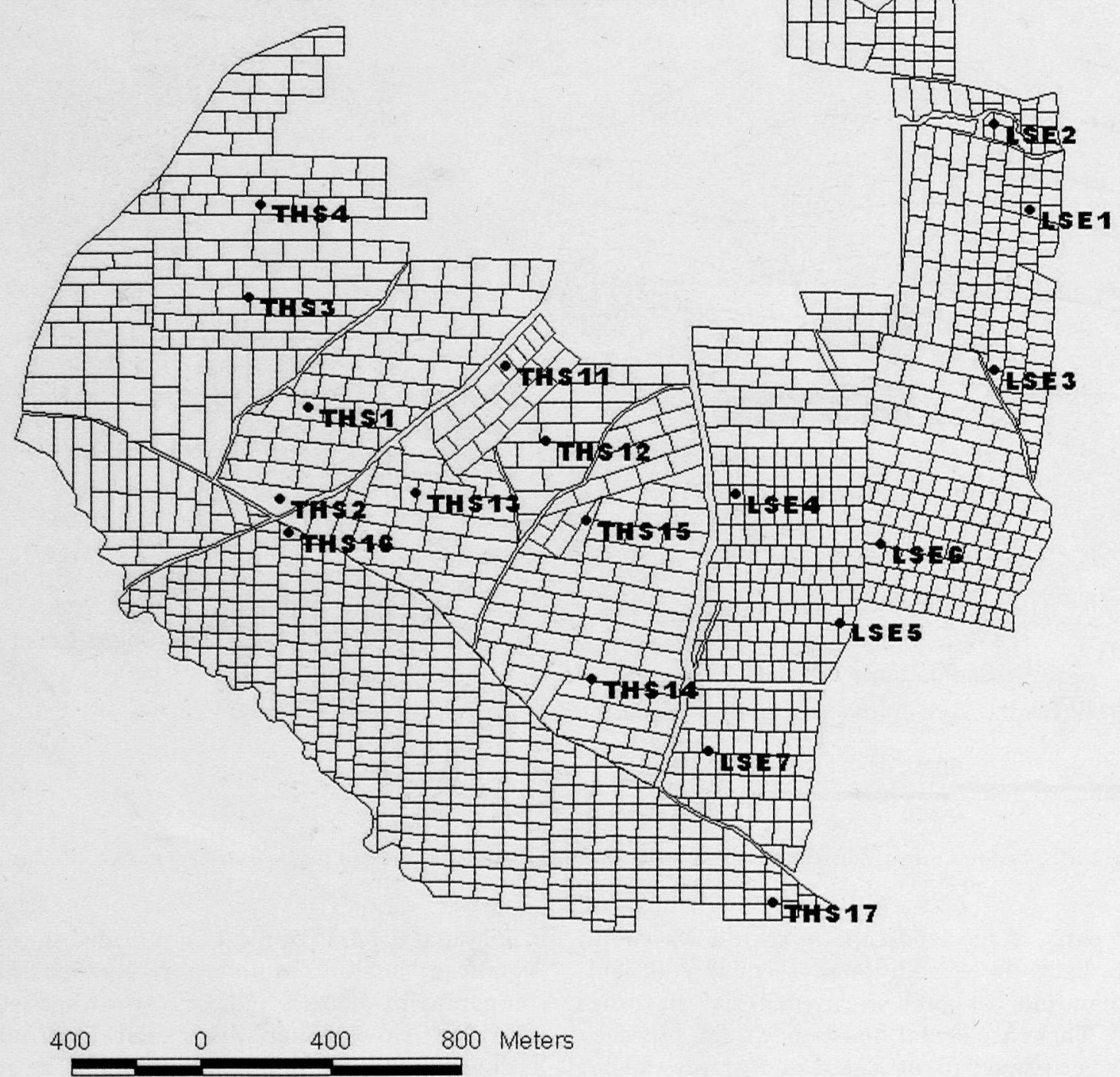

Fig. 6

Boeotia Survey: the LSE/THS sector, surface sites located over an area of $5.2 \mathrm{~km}^{2}$

14,000 or so hypothesised inhabitants of the GrecoRoman city of Thespiae (which lies directly adjacent to the area surveyed), conveying their household and farmyard rubbish out from the city and distributing it across their rural estates, rather than through the manuring and rubbish-disposal of the maximum 150 or so rural inhabitants we would hypothesise to have occupied the recognised small rural sites in this sector (Bintliff \& Snodgrass 1988b). However, for the purposes of this paper we can see how especially difficult it would be for fieldwalkers confronted by such densities to become aware of scatters of 2-3 coarse prehistoric sherds, which could be the only obvious sign of a vestigial prehistoric site as discussed above.

With such immense quantities of surface material, only a small sample of the non-site pottery was collected for cleaning and chronological analysis (total 3714 sherds) as opposed to merely counted on the groundsurface (Fig. 8). The statistics of this sample, which covered the entire area reasonably thoroughly, were illuminating (Fig. 9). Almost all the 
6. $J$. Bintcliff et al. DECONSTRUCTING 'THE SENSE OF PLACE'? SETTLEMENT, FIELD SURVEY, HIST REC: CENT GREECE
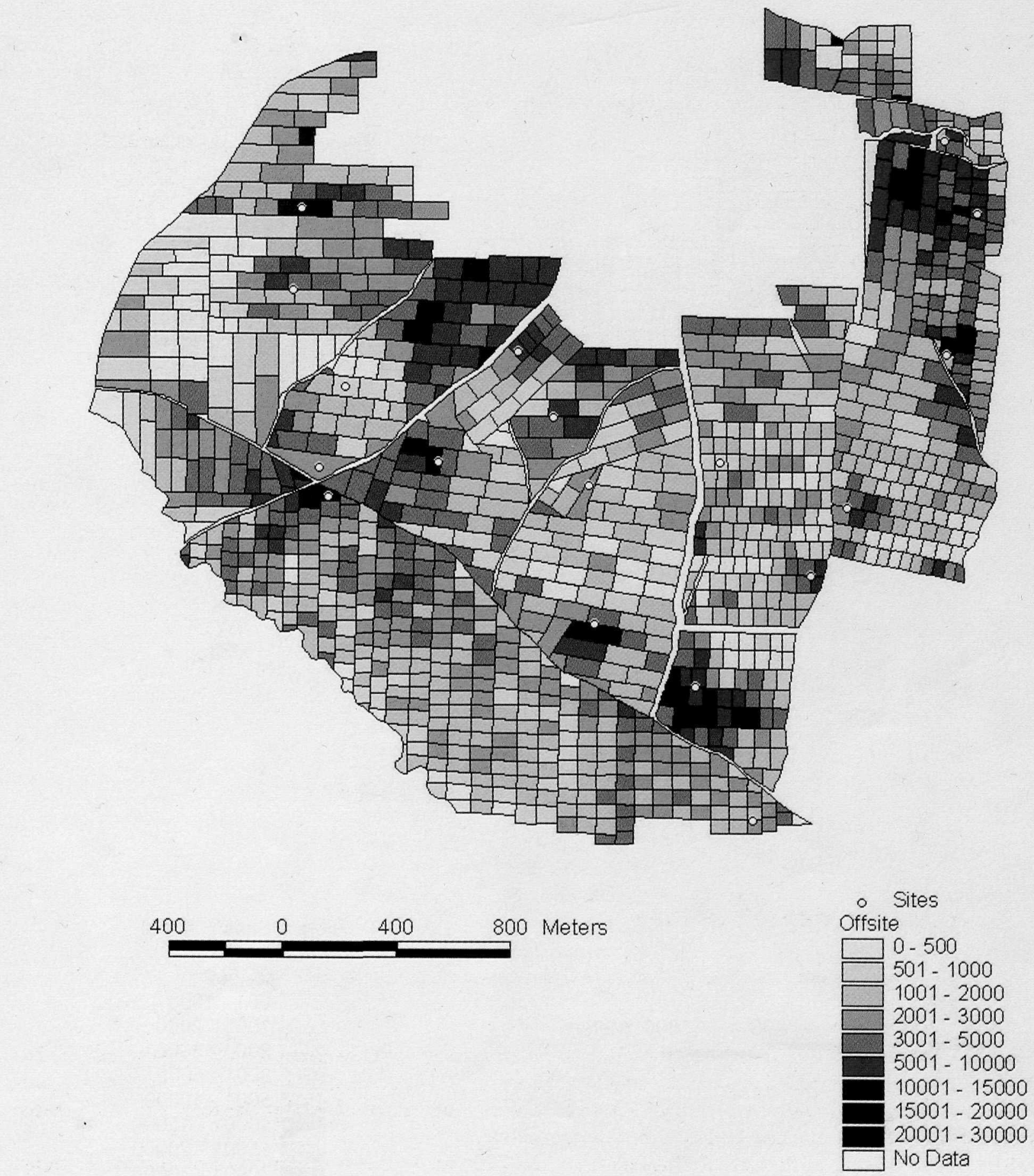

Fig. 7 a

Surface pottery density

(visibility corrected) for the LSE/THS sector, recorded by fieldwalking transect as density per hectare. Sites identified as rural settlements cemeteries shown in white 


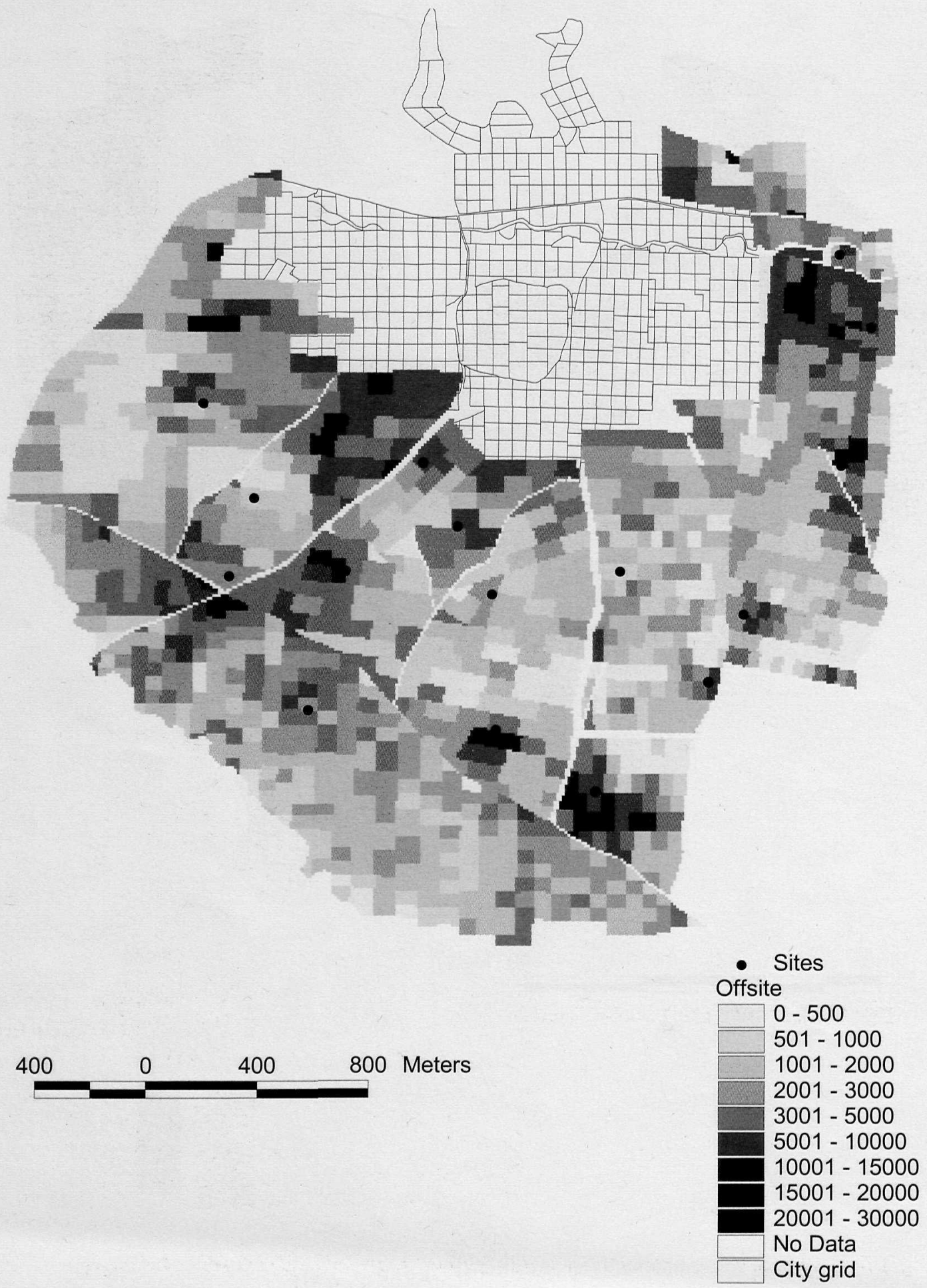

Fig. $7 \mathrm{~b}$

Location of LSE/THS sector in relation to survey grid of city of Thespiae to the north. Surface densities as in Figure 7a but filtered to smooth out transect boundary effects. All sites shown as black circles 
6. J. Bintcliff et al. DECONSTRUCTING 'THE SENSE OF PLACE'? SETTLEMENT, FIELD SURVEY, HIST REC: CENT GREECE
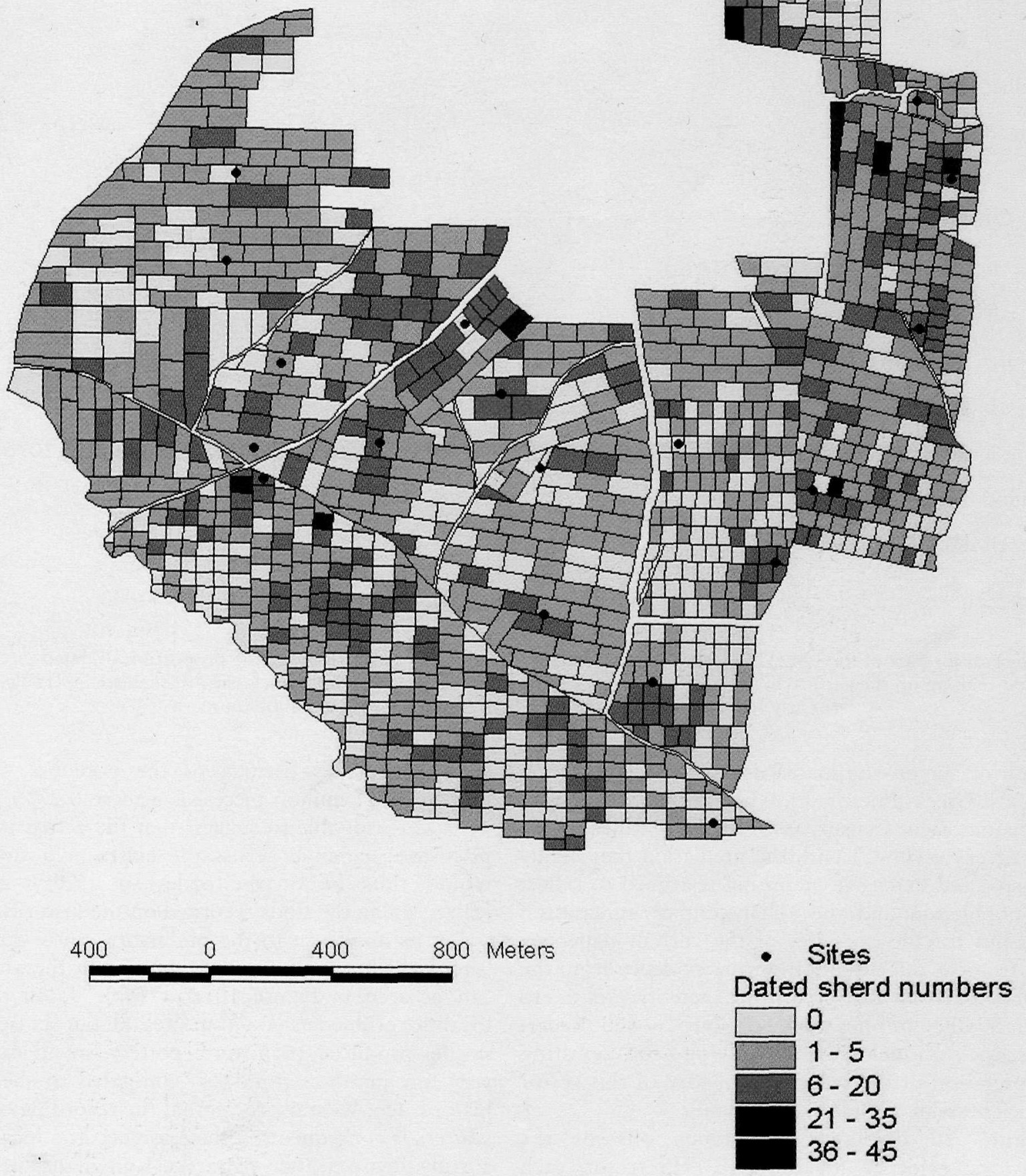

Fig. 8

Distribution of the sample of 3714 sherds collected from the LSE/THS sector for dating 
THE PREHISTORIC SOCIETY

\section{THS low numbers}

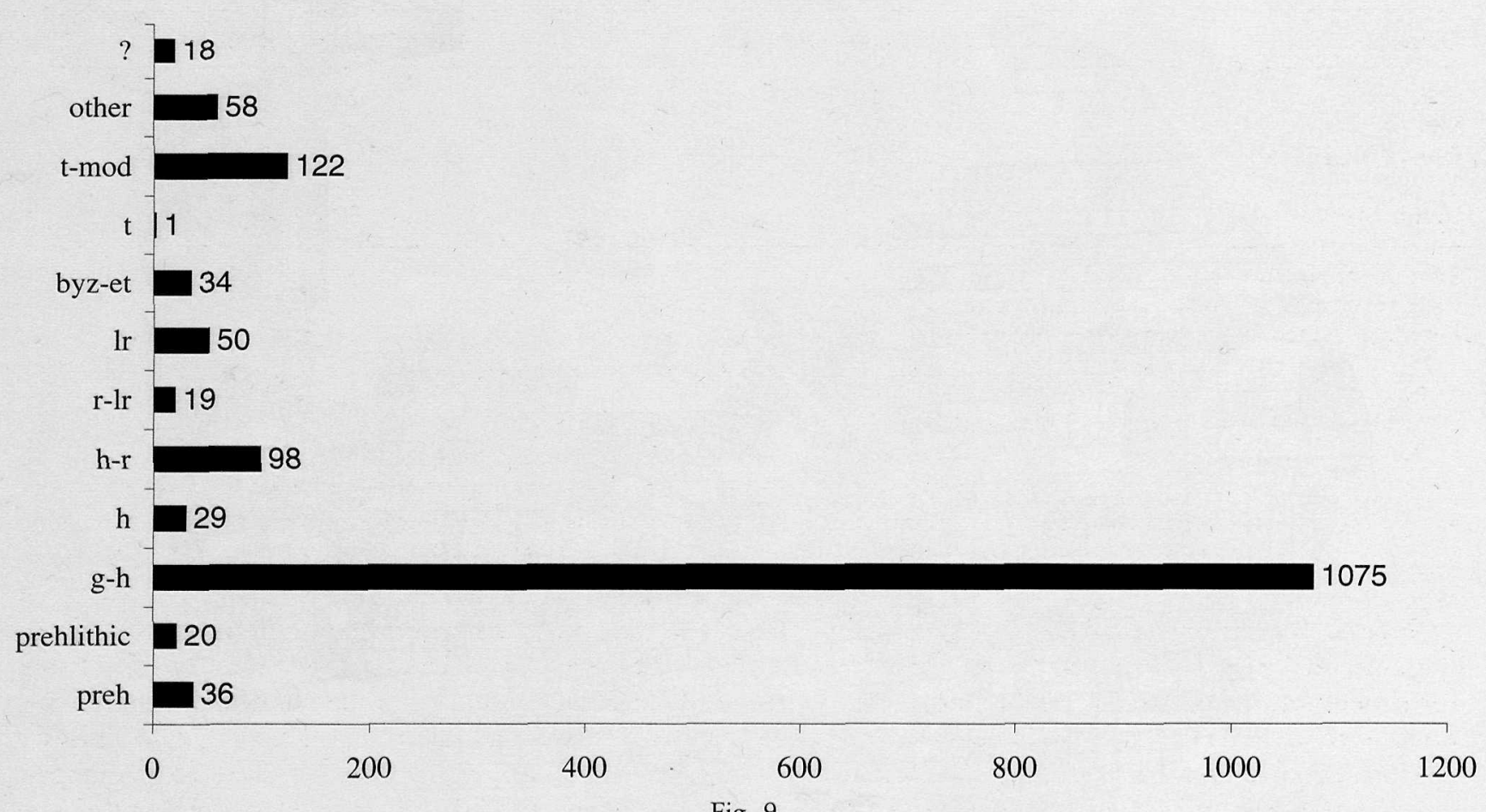

Fig. 9

Histogram for part of the LSE/THS sector (approximately one-third in area), showing the proportion of dated pieces per period making up the surface material. Key: preh=prehistoric pottery, $\mathrm{g}-\mathrm{h}=\mathrm{geometric}$-classical-Hellenistic, $\mathrm{h}=\mathrm{Hellenistic}$, $\mathrm{r}=$ Early Roman, $\mathrm{l}=$ =LateRoman, byz=Byzantine, $\mathrm{t}=$ Tukish, mod=modern

'manuring' or off-site material was deposited during Classical Greek times $(\mathrm{g}-\mathrm{h})$, when population density in Boeotia reached unsurpassed levels (Bintliff 1997c). This agrees very well with the prediction that highly intensive and extensive manuring is argued to reflect over-population and the exhaustion of agricultural land. But for the purposes of the current paper we wish to focus our attention on the evidence from the surface material for prehistoric activity, so as to evaluate the implications of our novel 'secret landscape' model for modifying the existing interpretation of the settlement history of this sector of the Thespian 'chora' or hinterland.

Figure 10 displays two dimensions of the prehistoric evidence for the LSE/THS sector, each retrieved via distinct spatial scales of investigation. Firstly, the shaded field transects demonstrate the location and number of prehistoric potsherds found in the small sample of 3714 sherds collected across the entire $5.2 \mathrm{~km}^{2}$ surveyed. Although the numbers (52) are tiny, one must bear in mind that the sample collected for all periods of the potential surface pottery ( 1.37 million pieces) is a mere $0.27 \%$ (Table 4). It is reasonable to suggest that the actual total of prehistoric ceramic across the entire area surveyed would thus be of the order of 19,000 sherds (disregarding the finds recorded on the historic sites).

Let us now turn to the prehistoric finds from the 'sites' which were formally identified in the area. As can be seen in Figure 10 and Table 4, on the 18 localities gridded as potential sites, all but six (ie, twothirds) produced prehistoric pottery, in all cases in very low numbers (total 25) compared to sherds of historic age. We must recall that the recording of such scatters is consequent on the existence at a locality of a truly dense scatter of Greco-Roman or medieval pottery, so that they should be seen as almost accidental 'windows' into our 'secret landscape' of prehistoric vestigial sites.

On the basis that prehistoric pottery deposited on an ancient landscape has almost no chance of surviving weathering to the present-day unless 


\section{J. Bintcliff et al. DECONSTRUCTING 'THE SENSE OF PLACE'? SETTLEMENT, FIELD SURVEY, HIST REC: CENT GREECE}

TABLE 4: THE BOEOTIA SURVEY PROJECT: THE LSE/TH.S. MICRO-SURVEY DISTRICT, PREHISTORIC FIND STATISTICS (PREHISTORIC POTTERY COLLECTED IN DATED 'OFF-SITE' AND HISTORIC 'SITE' SAMPLES)

\begin{tabular}{lcc}
\hline Phase & Historic 'site' collections & 'Off-site' dated collection \\
\hline FN/EH & $14-15$ & 22 \\
MH & $2-3$ & - \\
Transitional MH/LH & 1 & 7 \\
LH & - & 23 \\
\hline
\end{tabular}

Area of micro-survey $=5.2 \mathrm{sq} \mathrm{km}$

Total reconstructed surface ceramic quantity $=1.37$ million sherds

Sample collected for dating -3714 sherds $(=0.27 \%)$

Notes:

$1 \mathrm{MH}$ and LH were found on 3 historic 'sites', FN/EH on 9 historic 'sites'

2 'Off-site' prehistoric sherds in total, extrapolated from sample of $0.27 \%=$ minimum of 19,000 sherds

incorporated into a feature (pit, ditch, or other sealed deposit) (cf Kuna 1991; in press; Salac 1995), we would argue that scatters of several or more prehistoric potsherds are most likely to represent the vestigial surface indications of prehistoric levels (settlement, burial, or other foci of human activity). In terms of the LSE/THS sector under consideration, we consider the field transects and site collections with two or more prehistoric sherds as likely sites, and the remaining spread of single finds indicative of a fairly ubiquitous smearing of the entire district by lowdensity prehistoric material - again more plausibly due to near-site or on-site activity than off-site deposition. The interpretation in settlement terms we favour is this: prehistoric farmers in this district lived essentially in small farmsteads which were occupied for a generation of so, then a new farm was set up nearby to allow the old fields to regenerate (cf Kuna 1991). Over millennia, the process of horizontal displacement of farms created a continuous carpet of prehistoric site material, all of which progressively wore down to its present thin scatter appearance - so minimal in comparison to the immense density created by historic activity, not least the Classical manuring carpet.

Figure 10 also maps the location of 'sites' in the local district surrounding the LSE/THS sector, which fit the characteristics of a 'traditional' prehistoric site, ie, the finds are really abundant, extensive, and easy to spot even with historic reoccupation. Immediately north of the LSE/THS area lies the city of Thespiae, with plentiful Neolithic material from a 'magoula' hillock, then plentiful finds through the entire Bronze Age both from the area of the magoula and other points of the city where there is further Neolithic material. A few kilometres to the west lie the closelypaired sites of VM4/Askra (seemingly used in alternation), with likewise rich material from Neolithic to Late Bronze Age. Just south of the LSE/THS survey block lies the hill of Palaeokarandas, with extensive material of all the Bronze Age phases. I suggest that these richer sites represent larger, longerlived, widely-spaced village-hamlet foci (typical site types for the Fossey Gazetteer), between which we now need to to reconstruct the largely invisible remains of hundreds of small, short-lived rural farmsites.

We can also, from the current datable material in the THS/LSE collection, provide some chronological detail to this model. Early to Late Neolithic finds are absent in the LSE/THS sector, but abundant at Thespiae Magoula and at VM4/Askra (both unusually rich in perennial water supplies). Such a confined and scattered distribution of early farming sites fits the current model for this period, proposed by Andrew Sherratt (1981), and recently confirmed for Greece by van Andel \& Runnels (1995) and Johnson (1996). It rests on a scenario of pioneer farming settlements lying on or beside river plains and major springs, locations constrained on settlers by the limitations of hoe horticulture.

Also predicted by Sherratt is a dramatic expansion in the number, density, and spatial cover of settlements during the Final Neolithic and Early Bronze Age eras. This reflects a very different and new agricultural regime utilising plough traction, in which the drier interfluve soils are opened up for cultivation and settlement. Indeed the dominant period identified 

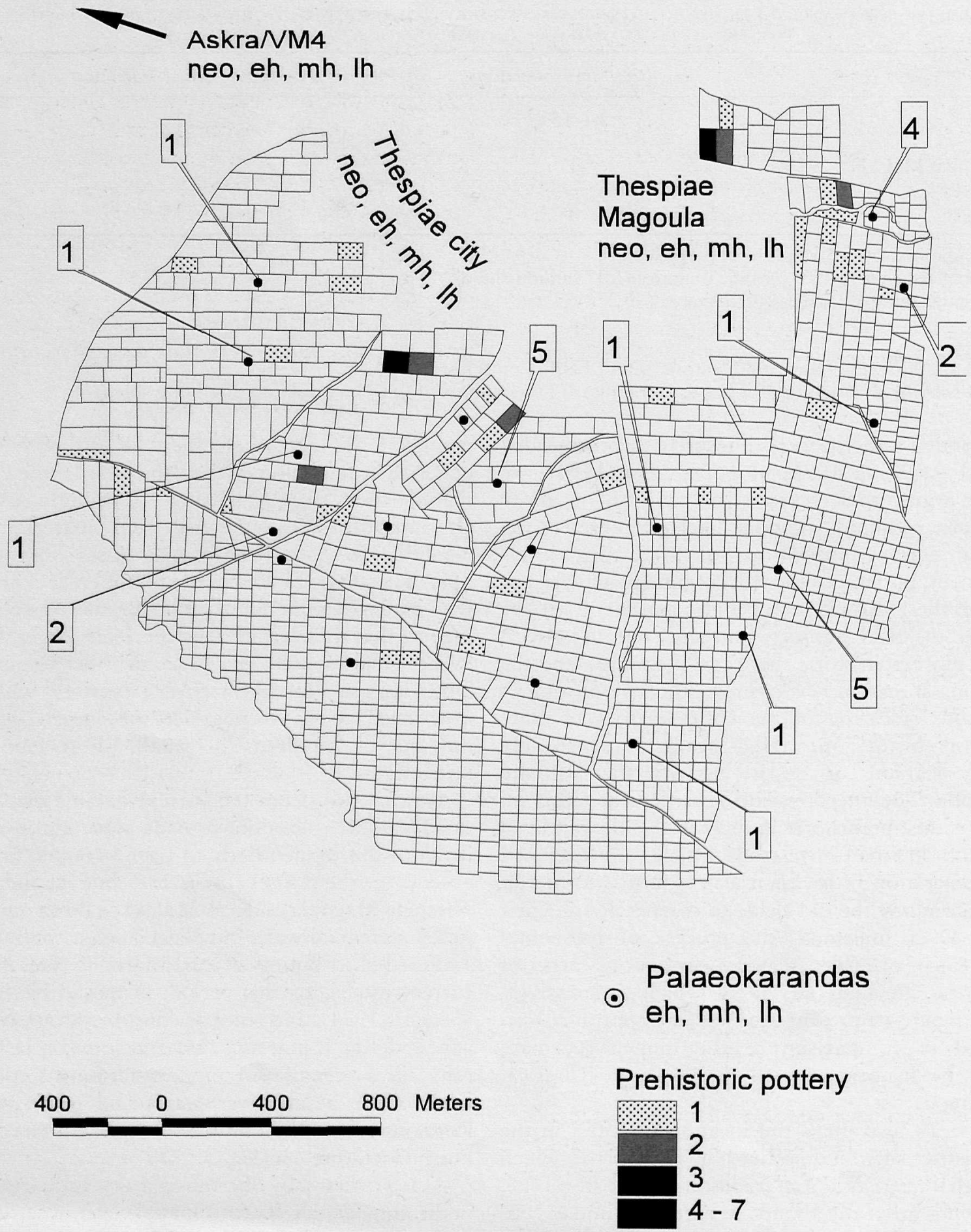

Fig. 10

Distribution of prehistoric ceramic finds from the fieldwalking transects of the LSE/THS sector (shown as grey scale-see key), and from the site collection grids of recorded sites (numbers of pieces per site in circles attached to site location points). Location of established prehistoric settlements in the district around the LSE/THS sector also indicated, with periods of occupation 


\section{J. Bintcliff et al. DECONSTRUCTING 'THE SENSE OF PLACE'? SETTLEMENT, FIELD SURVEY, HIST REC: CENT GREECE}

hitherto in the vestigial prehistoric site material from the THS/LSE collection, both in the off-site and onsite collections (Table 4) is Final Neolithic-Early Bronze Age. We might see the reconstructed innumerable small prehistoric farms of this era as a penumbra to a network of more stable, longer lived and larger rural nucleations (Palaeokarandas, Thespiae city, VM4-Askra). The network of those larger settlements is reminiscent of the pattern proposed by John Fossey, located with a 2-3 km radius of influence. Although it would be premature at this point to over-interpret the scantier dated evidence for the Middle and Late Bronze Age in the LSE/THS collection, it is striking that small site evidence is seemingly reduced during those phases. This might favour a model where population was more focused on the network of large rural sites, with less significant interstitial farmsite presence. A model emphasising increased settlement nucleation and the formation of a more territorial, parish-like settlement system for the mature to Late Bronze Age would certainly conform to current models being suggested elsewhere in Greece for these periods.

As for the issue of continuity of site occupation and more speculatively of population continuity, two aspects of the survey data need highlighting in the context of prehistory. Firstly we are now able to see that at the small farm-site level there is little continuity of locale in the short-term, and even in terms of a more general view of continuity within a small district - the model of a circulating farm-site relocation is particularly associated with earlier rather than later prehistory. At the level of the larger sites at wider intervals from each other - hamlets and villages, there is more apparent continuity of occupation, but this may be due as much to the geographical advantages of certain locations as to genuine continuity of a particular population. In neither case can we rule out short periods of abandonment of the larger sites, or of the small farm landscape as a whole, nor the possibility of the arrival of exotic settlers from outside the region - who might, for example, have merged with existing inhabitants or replaced them peaceably (or forcibly) on the most favourable village location sites. As we shall see, archival evidence for much later periods of the Boeotian landscape enforce such cautionary remarks.

\section{From the Dark Ages to late antiquity}

Returning to the scale of the whole region of Boeotia, we can move on in time to the post-Bronze Age 'Dark Ages'. On the traditional view, the general rarity of evidence for the Sub-Mycenaean to Middle Geometric periods of the Early Iron Age in Boeotia, as elsewhere in southern Greece, would be associated with a massive population collapse and a reversion to an egalitarian rustic society of 'Year Zero' type (Snodgrass 1980; Osborne 1996). There is actually growing evidence for status differences between 'Dark Age' settlements (in Boeotia and elsewhere), which is more plausibly seen as reflecting either the survival, or the reconstitution, of regional elite sites and unequal power relations between settlements within particular regions (Bintliff 1994). Since the data for Boeotia are very slight, we shall confine ourselves to commenting on the regional site distribution for the Geometric period as a whole. This is, however, based essentially on older extensive survey and is perhaps quite distorted by the well-known revival of southern Greek settlement numbers in the 8th century BC (Late Geometric phase) (Fig. 11). At least then by later Geometric times, but possibly further back into the 'Dark Age', the evidence associated with this distribution map can be interpreted as follows (see Bintliff 1994 for a full discussion): nucleated but mostly small-scale communities represent a village-hamlet network closely comparable to that already identified as the upper level of settlement hierarchy in the Bronze Age, with intervals of several kilometres frequently separating such minor population nucleations. Indeed very often the same locations are concerned as in later prehistory.

The results of the Boeotia Project intensive survey for this period are still in the process of evaluation. Not surprisingly a small number of farm-sites can be added to the above settlement model, but these are normally a feature of the end of the period - the Late Geometric, when the scenario of nucleation is beginning to be relaxed - both through the multiplication of villages across the landscape, and the growing number of farms in their presumed dependent 'parish' hinterland. On the other hand, it is early days in the 'source-critical' study of surface traces for the post-Mycenaean Dark Ages.

It is quite conceivable that sites of this age suffer discrimination in survey as a result of taphonomicrecognition problems. First, the proportion of poorly- 


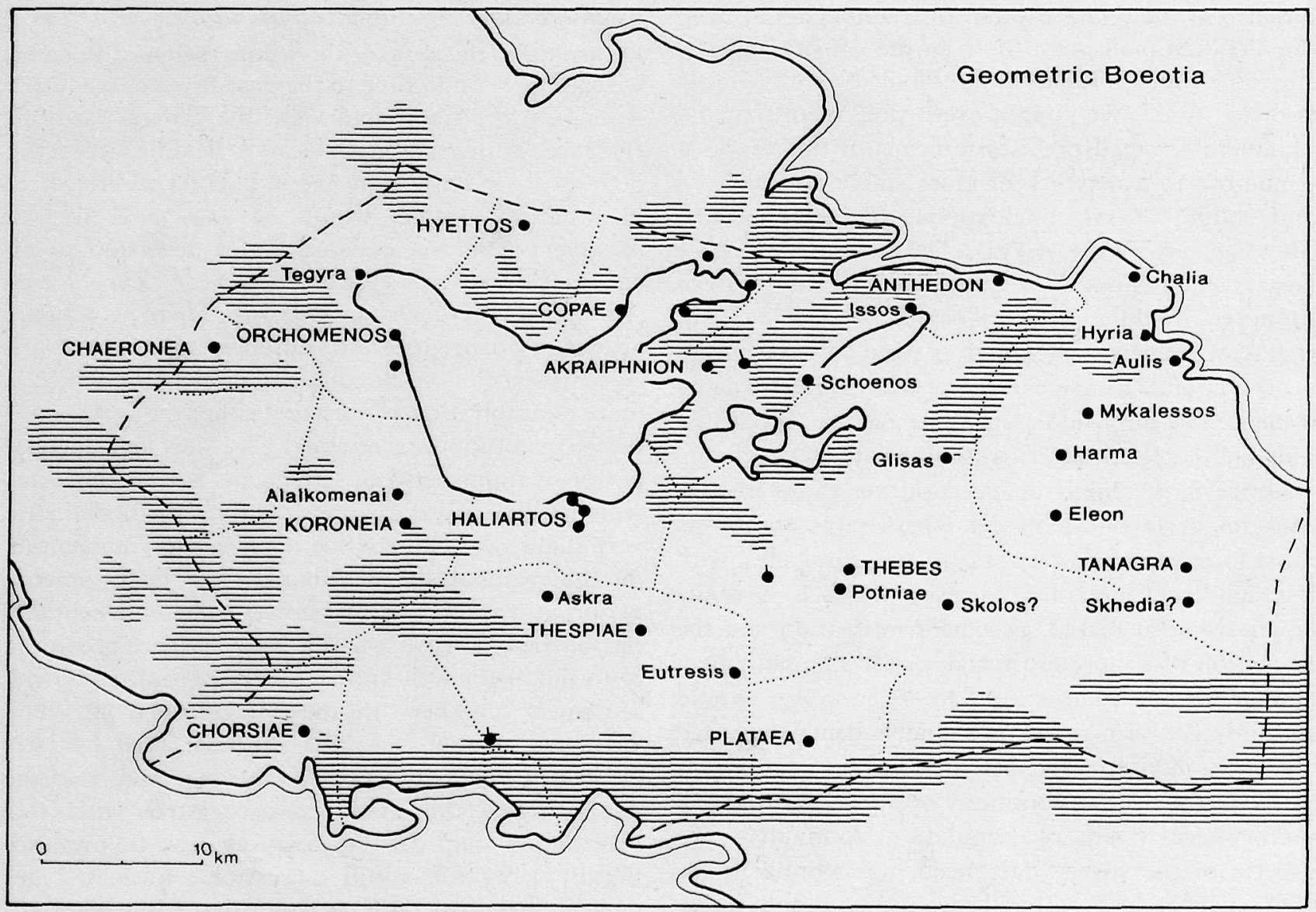

Fig. 11

Distribution of Geometric sites in Boeotia, prior to recent intensive survey work

datable coarser wares might be high; secondly, a limited human population would in any case leave slight debris. And thirdly and finally, the dominance of population nucleation on sites which were normally occupied in subsequent historic phases by a far more numerous population (who were also disposing of vastly greater quantities of harder-fired pottery), pre-supposes that finding the Dark Age pieces across a surface site would be very much hitand-miss. Although therefore the model outlined above, of widely-spaced hamlets and villages with low average populations and a scatter of satellite farms (both forms of site expanding rapidly towards the end of the period), may remain sustainable through further discoveries, caution is required for taphonomic reasons, and the settlement picture could be fuller and more varied than we suspect.
The Late Geometric pattern as just reconstructed provides a natural basis for a complete process of landscape infill to a far higher level of population during Archaic-Classical-Early Hellenistic times, culminating in a 4th century BC climax that would seem to surpass any population level reached subsequently (including the present-day) in the province of Boeotia (Bintliff 1997c). The Late Geometric village-hamlet network propagates itself, doubtless through settlement fissioning, so as to create what I have reconstructed as a complete network of nucleated village-hamlet sites across all the fertile landscapes of Boeotia (Bintliff 1994) (Fig. 12). The average radius of territory for this modular network of communities, at some $2-3 \mathrm{~km}$, agrees with the earlier calculation by Fossey. As the essential articulation of settlement and land use in a province that has always remained essentially 


\section{J. Bintcliff et al. DECONSTRUCTING 'THE SENSE OF PLACE'? SETTLEMENT, FIELD SURVEY, HIST REC: CENT GREECE}

agricultural, the half-hour radius community territory arguably represents a recurrent adaptation which need not imply cultural or ethnic continuity - indeed it can be shown to be a cross-cultural adaptation (Bintliff 1999). This also explains the persistence of the system in its main lines through the Greco-Roman era and on till late antiquity.

I have argued elsewhere (Bintliff 1994) that this relatively stable settlement-parish system forms the underlying structure for the emergence of the Greek city-state or Polis, in full agreement with Kirsten's Dorfstaat or 'village-state' model for the emergence of the typical city-state of Classical Greece (Kirsten 1956). During the Archaic era, all these village communities had the potential for polis formation, so I would term them 'proto-poleis', but through a process of competitive interaction, over time some 14-15 emerge as long-lived poleis, subordinating the remainder to satellite villages (Fig. 12).

If the dominant nucleated site network shows only minor modification through the more-than 1000 year long era of Greco-Roman antiquity (c. $700 \mathrm{BC}-\mathrm{AD}$ 600 ), there is a contrasted mutability in the small rural site sector of the settlement system. As noted earlier, the immense rise in the number of smaller GrecoRoman sites in Boeotia revealed through intensive survey (Bintliff \& Snodgrass 1985; Bintliff 1991), provides the more obvious dynamic of settlement variability over time, since in contrast to John Fossey's 1988 catalogue of mainly larger sites, we now see documented an enormous density of newly-discovered farms and villas in the landscape.

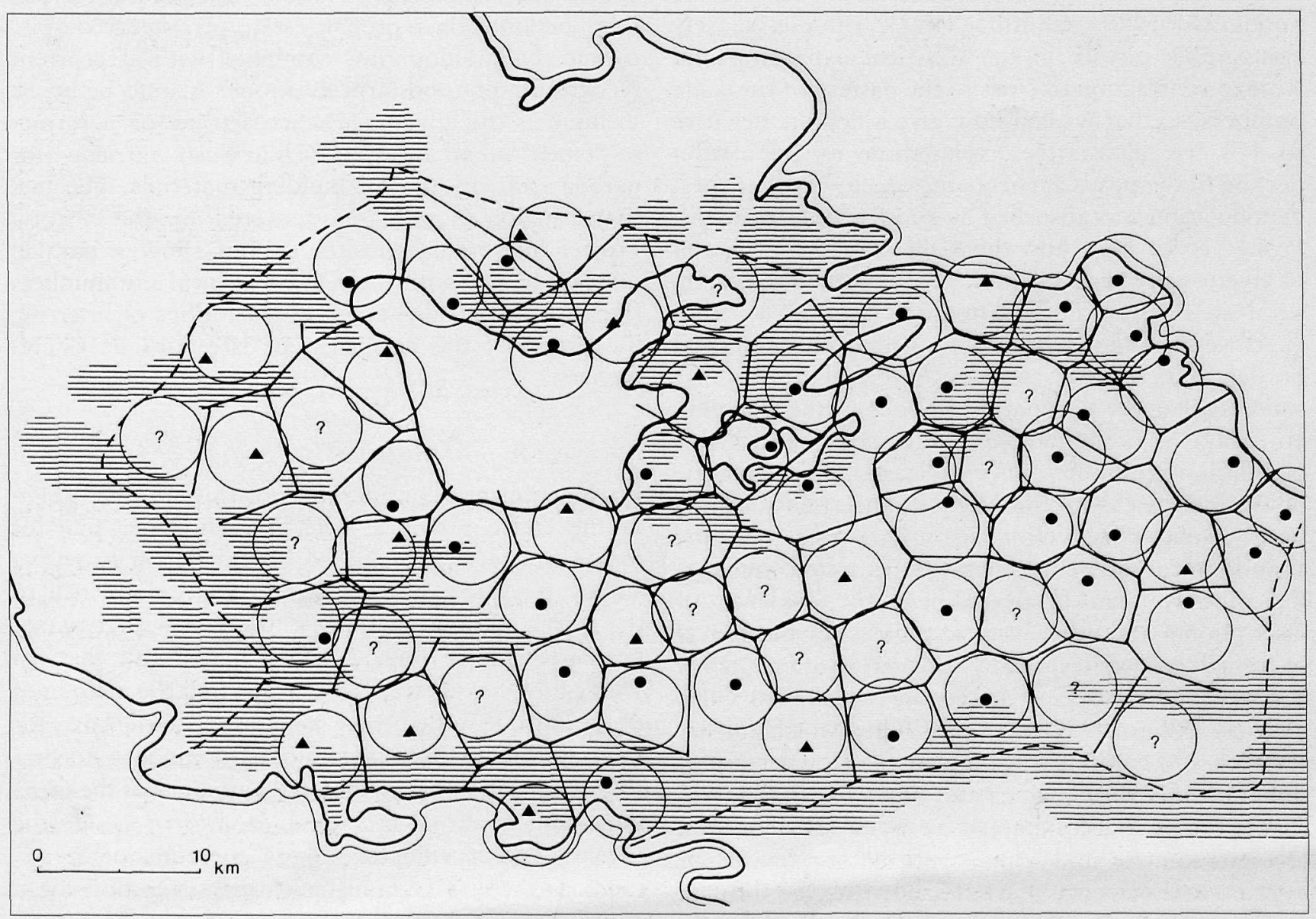

Fig. 12

Known and hypothesised nucleated settlement foci of Classical Boeotia (after Bintliff 1994). Modular core territories of $2.5 \mathrm{~km}$ radius indicated within Thiessen-polygon cells constructed for each focus. Classical towns (poleis) shown as triangles, villages as circles 
The enhancement of site density for all periods in Boeotia by a factor of 90 from the picture in 1988 (Table 2), allows us to focus, with immenselyexpanded data, on the preliminary comments Fossey passed for Greco-Roman settlement patterns. He identified an apparent Hellenistic and early Roman decline, followed by a small Late Roman recovery, all set against a settlement peak in Archaic-Classical times. We now suggest, on the basis of far fuller data, that after the Archaic-Classical peak there was a sustained high population throughout Early Hellenistic times. The drastic decline in site use then sees its inception in Late Hellenistic times (ie, after $c$. $200 \mathrm{BC}$ ), but the really dramatic site loss now seems to take place at the boundary to the early Roman era (at the turn of the millennium BC/AD), with a much stronger Late Roman recovery (c. AD 400-600). The Boeotia Project's intensive urban surveys (Bintliff \& Snodgrass 1988a; Bintliff 1992), offer a closely comparable picture in the Classical expansion and Roman contraction of cities to the pattern of rural site numbers, so that we can now give a definite negative to Fossey's alternative explanation to population decline in the post-Classical era, which was that rural depopulation was absorbed by a move into the towns. Figs $13 \& 14$ show how the early Roman contraction of Hyettos city persists into Late Roman times, despite rural site recovery in the latter era.

As we cross the Hellenistic to Roman chronological border, our relative confidence (based on historic sources) that the occupation of sites in the Boeotian landscape has remained continuous and with population continuity since at least Late Geometric times, must yield to considerable uncertainty. Along with a major reduction in urban area and the abandonment of many farm-sites, attested archaeologically, we can bring to bear the evidence of inscriptional and other historic sources for the arrival of foreign settlers (especially Italians). Arguments for a novel land-use regime based on commercial villae (Alcock 1993; 1997) are a possibility worth further research and could involve a change of ownership of some of the surviving estates into foreign hands. Unless this was accompanied by a general relocation of estate centres and some confirmatory textual or inscriptional evidence it would, however, be difficult to document such a discontinuity at the site level. In the area covered by the Boeotia Project, Roman farms tend to be sites that had been founded in Classical or Hellenistic times, and once a lively land market is in operation it is hard to be sure whether the estate is changing hands or not. These questions are clearly at the heart of our understanding of what happened to the countryside with incorporation into the Roman Empire, so future research will certainly focus on resolving these current uncertainties.

The same kind of problem is raised when we consider the dramatic revival of farm-site numbers documented by the Boeotia Project for Late Roman times (Bintliff 1991). Although some sites survive in apparent continuous use from Hellenistic and Roman times (if not from Classical times) on into the 5th-6th centuries $\mathrm{AD}$, the great rise in numbers represents either refoundation or new foundation of farm and villa sites, together with some larger rural nucleations. It is notable, however, that a high percentage of refoundations are at the sites of Classical Greek period farms, seemingly abandoned for centuries. Can this phenomenon represent estate persistence despite owner change, doubtless combined with a recurrent recognition of good farm locations? Also to be borne in mind is the advantage when settling on a former settlement site of a locality rich in waste nutrients (for garden cultivation) and building materials. The fact that usually, in the areas covered by the Boeotia Project Survey, urban sites do not show a parallel increase in size with the revival of rural site numbers (Figs $13 \& 14$ ), also makes one cautious of inferring the origin of the new class of late Antique estateowners.

\section{Medieval to post-medieval}

If we commence consideration of this era once again at the entire province level, a preliminary map of major Medieval sites, based essentially on extensive survey (Fig. 15), bears a significant resemblance to the Greco-Roman village-hamlet-town network presented earlier (Fig. 12). We may recall that, in 1988, John Fossey was led to argue that the main lines of the antique settlement system provided the basis for the traditional village system of early modern Boeotia (Fig. 1). It can be seen that a large number of the more important medieval foci are indeed at or beside the sites of recent villages. Taking these major trends together there is certainly a strong suggestion for a continuity of settlement focus if not surviving population in at least a significant number of locations (ancient town/village $\rightarrow$ medieval village $\rightarrow$ early modern village). 


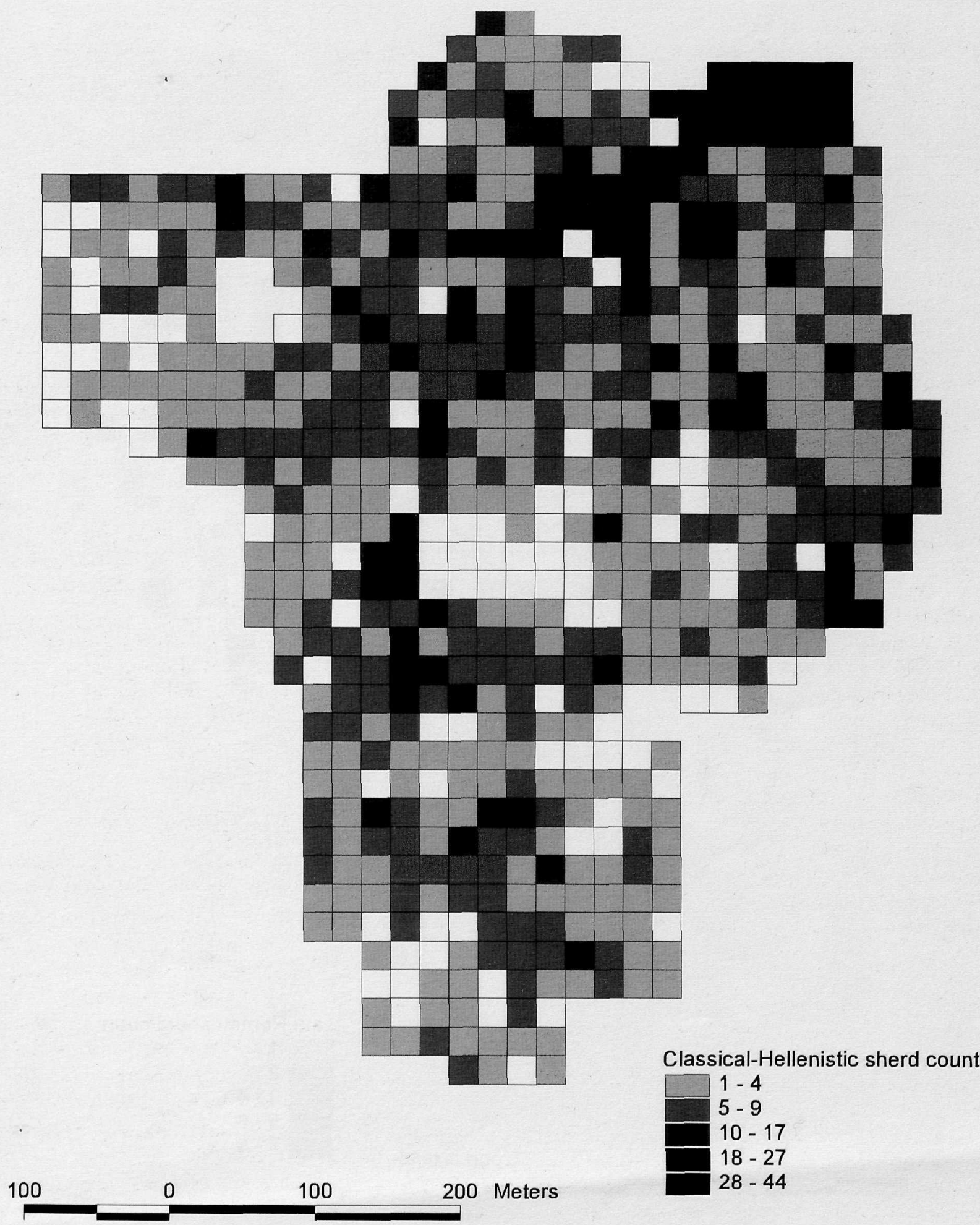

Fig. 13

Surface survey of the city of Hyettos, north Boeotia (Boeotia Survey Project). Basic grid unit $20 \times 20 \mathrm{~m}$ in size. Distribution of Classical-Hellenistic finds from the dated collection sample 


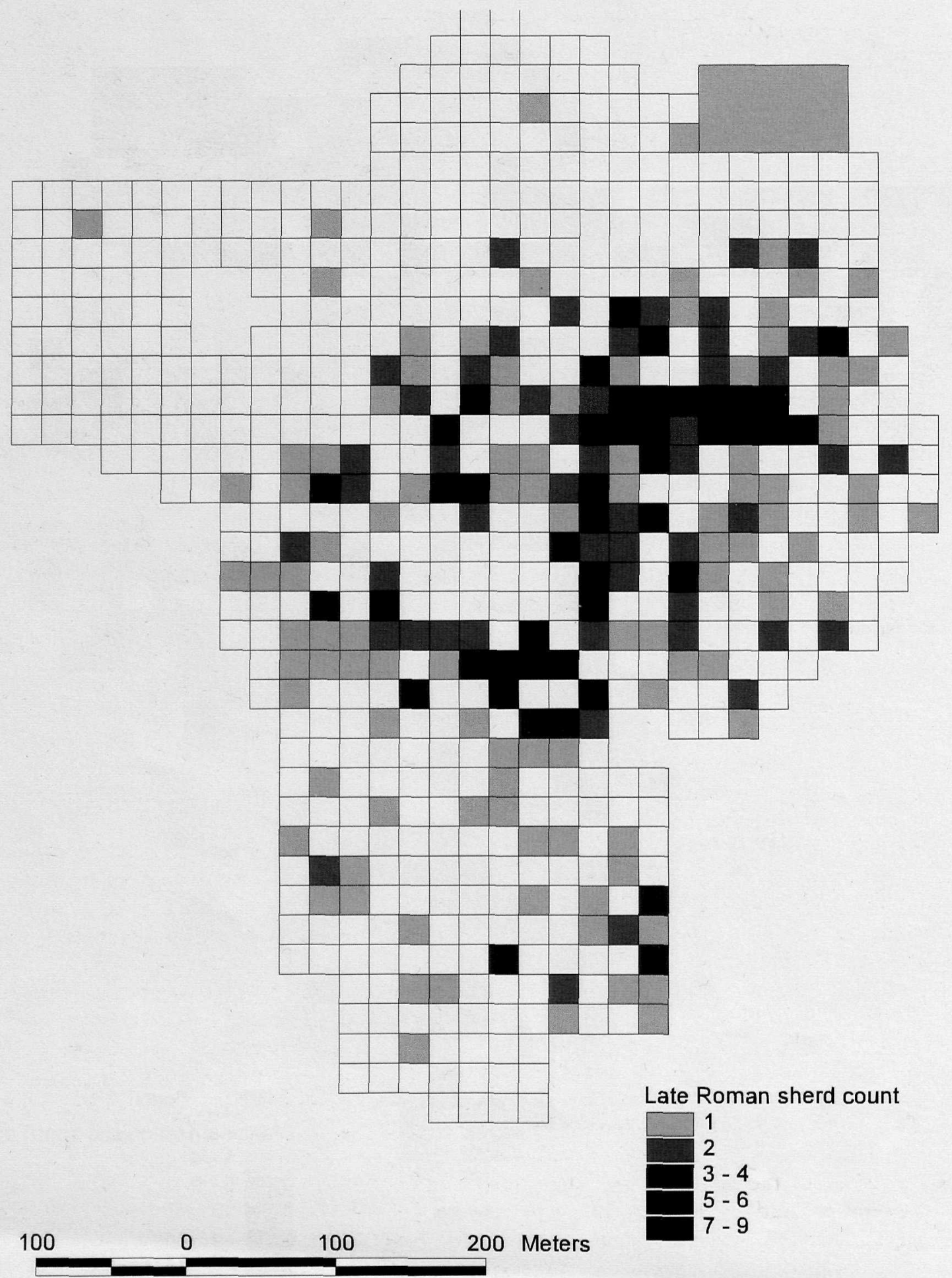

Fig. 14

Surface survey of the city of Hyettos, north Boeotia (Boeotia Survey Project). Basic grid unit $20 \times 20 \mathrm{~m}$ in size. Distribution of Late Roman finds from the dated collection sample 
6. J. Bintcliff et al. DECONSTRUCTING 'THE SENSE OF PLACE'? SETTLEMENT, FIELD SURVEY, HIST REC: CENT GREECE

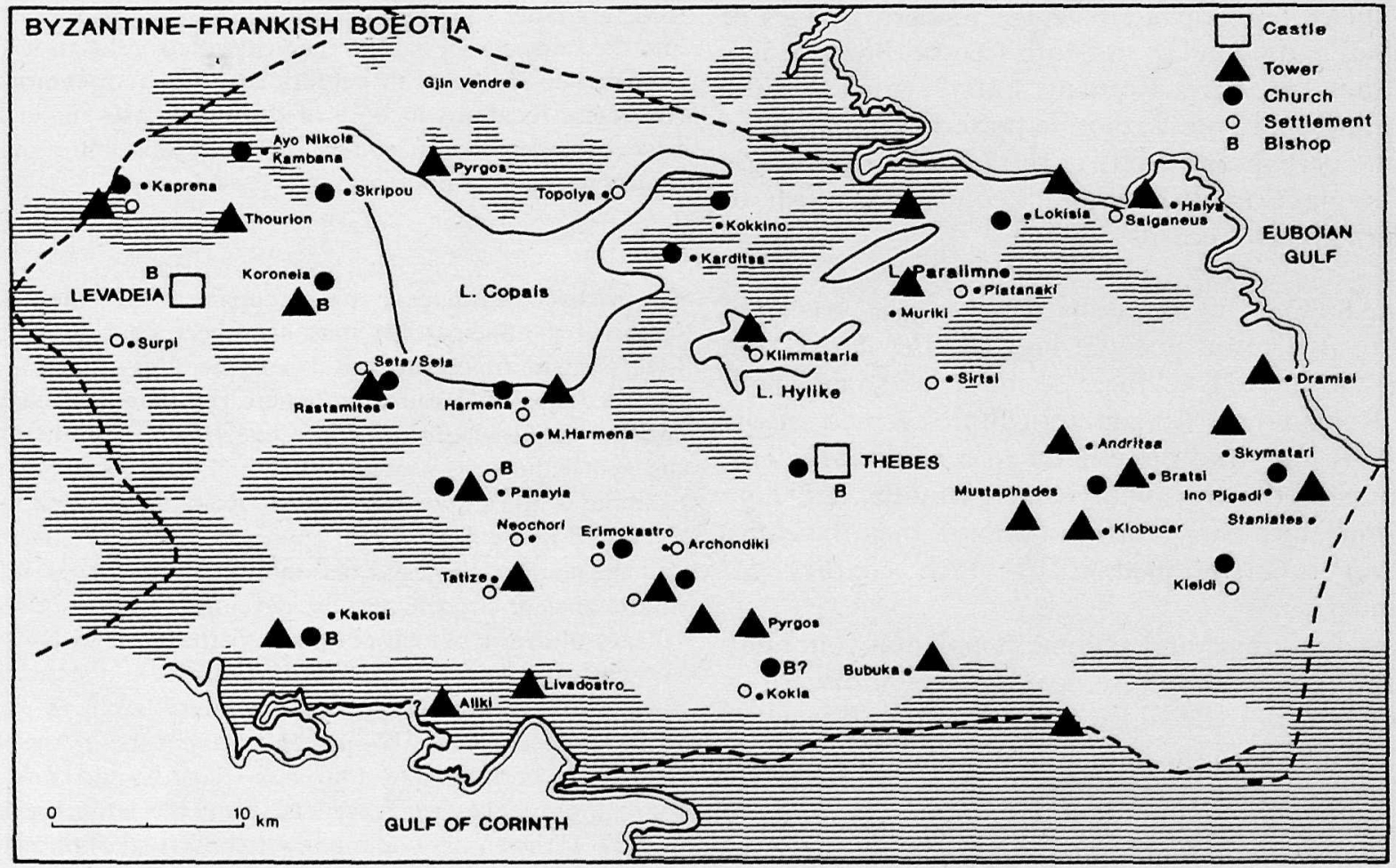

Fig. 15

Major monuments and recorded historic sites in medieval Boeotia (pre-intensive survey)

However, the research conducted by the Boeotia Project into case-study sectors of the region, and into specific archival sources, both enriches and complicates our picture of the evolution of settlement in post-Roman times, whilst raising serious doubts concerning the degree and significance of continuity of occupation in the landscape.

Let us turn first to the additional evidence which intensive survey provides (Bintliff 1991; 1995; 1996; 1997a). Unsurprisingly, it produces a very notable increase in site density. Whether we consider Byzantine, Frankish, or Ottoman period distribution maps for the areas fieldwalked by the Boeotia Project, we find very many new (usually smaller) rural sites that are interstitial to the larger village sites (often known previously) and largely of a suspected dependent nature to those nucleations. Such farm and hamlet sites, largely unrecognised by previous extensive survey, conform to the pattern observed in prehistoric and ancient times, in that they are often short-lived and fluctuate considerably in number from phase to phase (usually in agreement with the overall economic and political prosperity of the region of Boeotia as a whole).

More detailed information can be gleaned through study of a number of the larger village sites, with their longer archaeological record, richer material finds and opportunities for archival referencing. In earlier publications I have discussed specific examples of apparent or inferred continuity between late antique and early modern times on focal larger nucleated sites which have been subjected to intensive surface survey by the Boeotia Project (Bintliff \& Snodgrass 1988a; 1989; Bintliff 1991; 1995; 1996; 1997a). For example (see Fig. 11 for locations):

ASKRA (west of the village of Palaiopanagia in SouthCentral Boeotia; Fig. 1): finds of Late Roman, Early?, and Middle Byzantine pottery. This seems to relocate directly to the nearby site of VM4 (Late ByzantineEarly Turkish finds), which in turn seems to relocate directly to the modern village of Palaiopanagia/ Askra (Late Turkish to Present archival record). 
THESPIAE (directly south of the modern villages of Thespiai and Leondari in South-Central Boeotia; Fig. 1): finds of Late Roman, Early?, and Middle Byzantine, and Late Byzantine pottery. This seems to relocate perhaps indirectly to the adjacent hill villages of Thespiai/Erimokastro and Leondari (Turkish to Modern archive records).

HALIARTOS (immediately west of the town of Aliartos in Central Boeotia; Fig. 1): after destruction of the city in $171 \mathrm{BC}$ there seems to be some smallscale Roman-Late Roman agricultural activity at the site. This may lead directly on to a medieval village just outside the city (with Early?, Middle, and Late Byzantine, and Early Turkish pottery), then the entire location is abandoned till a 19 th century $\mathrm{AD}$ refoundation.

However, ethnic and genuine population continuity is unlikely to be anywhere near as straightforward as this simplified archaeological account would suggest. We shall take each site in turn (plus an additional site Hyettos, lying between the villages of Loutsi and Pavlos in North Boeotia; Fig. 1), and review the fuller evidence available, not least from recent archival research.

\section{ASKRA}

The plausible identification of this ancient village site with the Byzantine and Frankish community of ZARATOBA suggests an influx of Slavs merging with the local GrecoRoman population, or even total replacement of same, during the Early Byzantine era (probably between the late 6 th and 8th centuries $\mathrm{AD}$ ). We have made a case for a deliberate relocation of the community to the nearby site of VM4 in the early 13 th century AD, by an incoming Frankish landowner, where, under the new name of 'Panagia' the village is listed as Orthodox (by then indistinguishable from 'Greek') in the earliest Ottoman regional census (15th century AD) (cf Figs $15 \& 16$ ). The Ottoman sources and early western travellers show clearly that the population of Panagia-VM4 abandoned that location in the 17th century and moved to the present-day village of Palaiopanagia at a time of severe political and economic dislocation in the region. However, it is well worth observing that the archaeological evidence on its own would probably have led us to a contrary series of interpretations to those better attested in our archival sources. Thus the promising case for continuity at Askra from late antiquity through to the end of Middle Byzantine times in archaeological terms, masks the strong archival case for a major or possibly total replacement of population by foreign colonisation. On the other hand, the creation of a new village at VM4 at the turn of the 13th century AD, although at the behest of a Frankish lord, arguably represents continuity of village population, and the same can be said of the next village relocation to its current site in the 17 th century $\mathrm{AD}$. The reorientation of settlement locations in both of the latter cases might have been considered archaeologically as evidence for discontinuity in regional populations.

\section{THESPIES}

The archaeological case that occupation over the eastern sector of the ancient city may have been continuous from Late Roman times through Byzantine times and on into recorded medieval sources - where the Frankish village is cited as 'Erimokastro' (Fig. 15), meets no contradiction in the sparse historic sources, and thus remains a potential example of the survival of a Greco-Roman community into the high Middle Ages. Then, however, both the archaeology and the sources suggest a discontinuity between the village on the ancient city site and the development of the two hill villages above it, which continue to the present-day (now known as Thespiai and Leondari). 'Erimokastro' has disappeared by the time of the (Ottoman) archives for the 15 th-16th centuries $\mathrm{AD}$ and only reappears in the 17 th century - both in the Ottoman records and those of contemporary western travellers; from the latter we learn that the 17 th century community is comprised of three parts - one on the ancient city once again, the other two being the modern hill villages. Current research on the ceramics at the city may hopefully confirm a clear gap for the missing phase in the records, but it is a relatively short phase to try and separate out, in an era where ceramic typology is just getting established (Vroom 1997). Yet there is strong circumstantial evidence to suggest that the medieval village of Erimokastro, still only on the ancient city site, was abandoned for some two centuries, whilst the hill village bearing its name till recently can also only be documented from the 17 th century.

The vital evidence comes from the other hill village, immediately beside modern Thespies-Erimokastro. This is now called Leondari, but till recently was always known under its original name as Kaskaveli or Zogra Kobili. This is a village of Albanian colonisers dating from the turn of the 14th/15th centuries $\mathrm{AD}$ (well recorded in the Ottoman archives - cf Fig. 16), and our experience in working with such new foundations in Boeotia (Bintliff 1995; 1997a) is that these settlers were directed to recolonise abandoned or almost deserted Greek village locations. The revival of Erimokastro with its name intact could indicate the return of the descendants of the original village some 300 years after leaving it (who resettled the ancient city site and founded a new quarter on a hill above). On the other hand, the name is a descriptive toponym ('deserted fort') that may have remained attached to the area beside the late antique fortification to the city, a walled enceinte which remained a prominent monument till the end of the 19 th century. Thus the story of Thespies is clearly discontinuous, and there is 


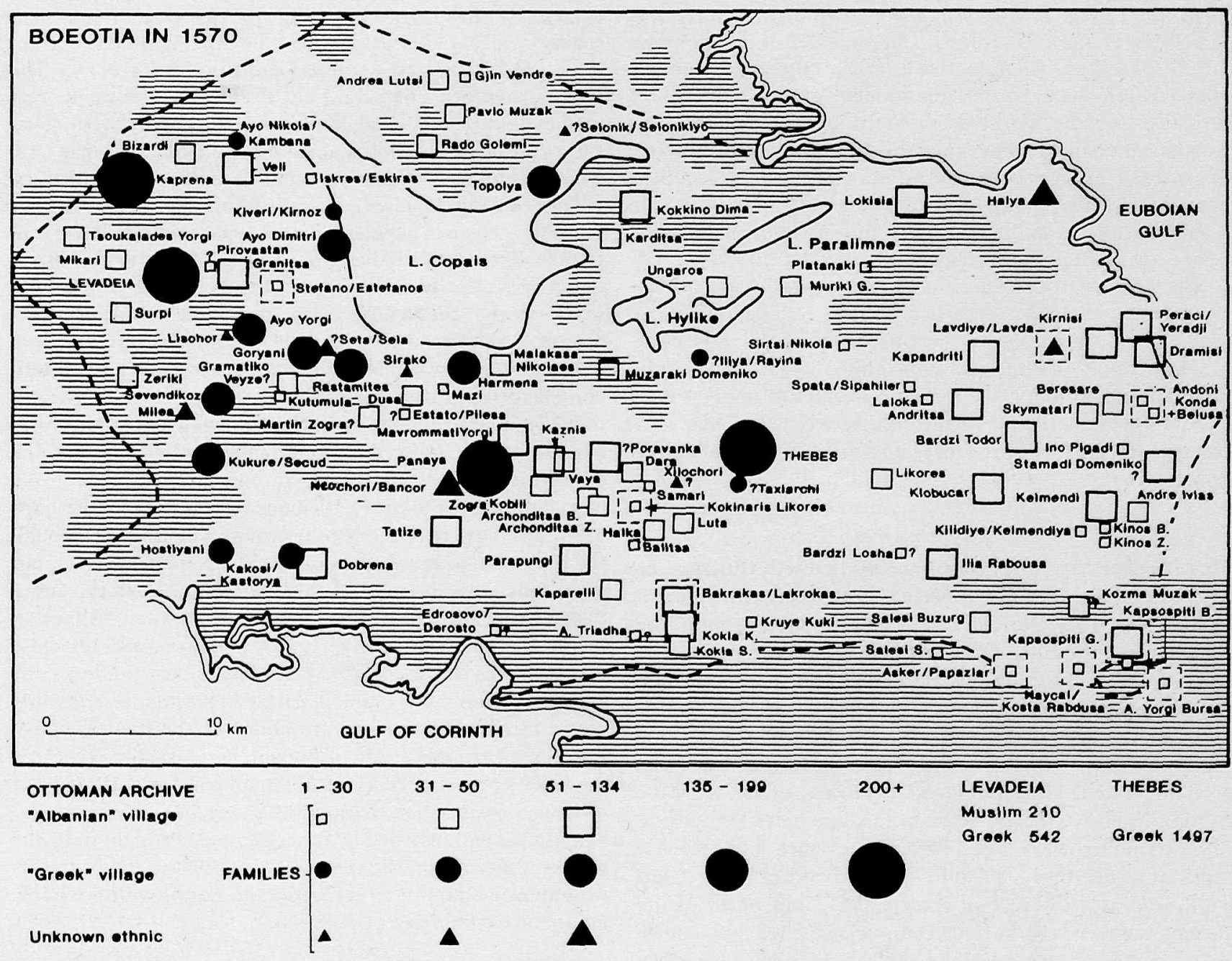

Fig. 16

The population of Boeotia in 1570, based on the Ottoman census lists for villages and towns (catalogued and translated by Prof. Machiel Kiel, places located by the author)

ethnic replacement, whilst we remain to uncover fresh evidence to support the additional hypothesis of an indirect population continuity via an intermediate site in the region.

\section{HALIARTOS}

Here the case for continuity is weaker from the beginning as there is no evidence for a nucleated community on the ancient city plateau or beside it by Late Roman times. On the other hand, there is a small nucleated Byzantine settlement focus close to the ancient town and this seems on the surface archaeological evidence to have flourished and grown in size in Frankish (Late Byzantine) and especially Early Ottoman times. The potential links from antiquity are further undermined by the case that can be made from historic sources that this medieval and Ottoman village was named 'Harmena' (cf Figs $15 \&$ 16): this is an early Slav toponym for 'church' (Dr P. Soustal, pers. comm.). The later fate of this Greco-Slav or possibly incoming purely Slav community is a complex one. Both archaeologically and historically the settlement and its name as stated disappears. We have made a plausible case that the location was deserted in the troubled 17th century for an upland village called Mavrommati Harmena (a kilometre to its south; cf. Fig. 15), which ought then to have been Greco-Slav in original ethnicity. Yet this village in turn is abandoned by the 19th century and its population moves to merge with the Albanian in origin and still currently occupied village of Mavrommati (Yorgi), further away in a different village 
niche (cf Figs $1 \& 16$ ). Till the end of that century the 'parish' of Haliartos is cultivated as an extension of another village. Modern Aliartos town (Fig. 1) was refounded without reference to its abandoned predecessors as a residence for the workers employed by the British Lake Copais Company at the end of the 19th century, but owing to its excellent communications and intermediate location between the two main provincial towns of Thebes and Livadhia, has gradually developed into a secondary service centre for surrounding villages.

The lessons from Haliartos are particularly difficult to assimilate and apply to earlier periods of Boeotia where such detailed archives are lacking: once again it is clear however that locational continuity need not imply population continuity, site migration need not imply a new population, and finally close links between an older and younger site may conceal a merging or replacement of ethnic groups.

\section{HYETTOS}

This ancient city site was long recognised (Etienne \& Knoepfler 1976) as disconnected from the early modern village network. Our survey work on and around the ancient town (Bintliff 1992) has elucidated another complex story of relocations and discontinuities. The extensive Late Roman city showed, on total survey, minimal evidence for post-7th century AD activity beyond farmstead level (one sherd of Slav Ware merely informs us of the presence, probably in the final phase of the town, of Slavs in the region). Intensive survey in the immediate hinterland of the city was nonetheless highly successful, since it revealed a series of small rural sites, all within a band of some $1 \mathrm{~km}$ width and at a distance of a mere $0.5-1 \mathrm{~km}$ north of the ancient town, whose surface ceramic sequence (still under analysis) may span in total the entire time-range from early medieval on to the 19th century. Apparent typological overlaps might be read as indicating a general continuity of a small rural population in the near vicinity of the ancient city till the end of the last century, but as yet no suggestion is forthcoming of archaeological overlap between the final material from the city and the oldest finds from the succeeding rural sites.

Archival sources, in any case, once more disrupt the potential archaeological continuities across the five closelyspaced medieval to post-medieval rural sites. We do not as yet know the name(s) of the Byzantine and Frankish period hamlets (Site names $\mathrm{CN} \mathrm{3,8,15}$ and 17), so it remains unclear if these were inhabited by a drastically-diminished remnant of the Greco-Roman city population of Hyettos, or by incoming Slav settlers - or a combination of the two. But the earliest Ottoman village census for the district is unambiguous: no 'Greek' villages survive by the turn of the 14 th and 15 th centuries, and the entire area has been recolonised by Albanian settlers. The surviving modern villages of the district (just outside the area of our field survey) are founded at this time by Albanian colonisation (Pavlo [Muzak], and [Andrea] Loutsi) (Figs 1 \& 16). The latest member of the chronological sequence of medieval-post-medieval hamlets in our archaeological survey is site $\mathrm{CN} 4$, whose ceramics suit the Ottoman era, and this must be another Albanian foundation - that of the village of Gjin Vendre - recorded for this locality in the Ottoman censuses as founded at the same time as Pavlo and Loutsi (Fig. 16). To confuse matters further, archival detective work and the standing ruined buildings at the CN4 site show that the Vendre village passed into the hands of a distant Greek monastery by the 19th century and became a dependent grange. In so doing its name was hellenized into 'Sta Dendri' (now abandoned).

In summary, it remains to be shown whether the rural hamlets which succeed the city of Hyettos represent the continuity of a (severely diminished) late antique population, or a Slav resettlement of the area, or perhaps both. It is more reasonable to postulate a continuity through the Byzantine to Frankish periods for this hamlet cluster, but there must have been wholesale abandonment of the entire district during the 14th century $\mathrm{AD}$, when Albanian recolonisation confusingly creates a new hamlet in close proximity to those of the preceding Greek and/or Slav farmers (although as noted earlier, targeted resettlement seems to have been deliberate policy of the final Frankish and early Ottoman lords of Boeotia). It is finally unclear if the CN4 site remained as an Albanian hamlet by the time of its transformation into a monastic grange, or whether it was abandoned and resettled by other peasants brought in by the monks. Once again, the ceramic sequence and the processes of settlement stability or relocation do not provide a reliable guide to continuity of population.

\section{THE OTTOMAN ARCHIVES}

As has become apparent from the immediatelypreceding account, we have found an invaluable corrective, in newly-accessible archival sources, to the rather coarse-grained picture which the archaeology provides for the medieval and post-medieval centuries. Chief amongst these in quality, quantity, and reliability, are those maintained by the early Ottoman Empire (Kiel 1997; Bintliff 1995; 1997a). Sparser in detail and preservation are the Byzantine and Frankish texts (Koder \& Hild 1976; Lock 1995). Whereas the overall network of Greco-Roman nucleated sites (towns and villages) (Fig. 12) does bear a general resemblance to the major nucleated sites in the medieval era (Fig. 15), and the modern village 


\section{J. Bintcliff et al. DECONSTRUCTING 'THE SENSE OF PLACE'? SETTLEMENT, FIELD SURVEY, HIST REC: CENT GREECE}

network (Fig. 1), we have now seen good reason to doubt if this reflects continuity of population, or even necessarily continuous occupation by different populations. Some localised continuity may have occurred, but more commonly a location witnesses recurrent use as a focal settlement as a result of geographical advantages and previous investment in land clearance, terracing, etc.

Moreover, both the detailed evidence from our intensive archaeological survey windows, and the archives, tell us something missing from the rather generalised comparison of the settlement networks for the three time periods (ancient, medieval, and early modern) just reintroduced. In the 12 th-13th centuries $\mathrm{AD}$ intensive survey reveals many more hamlets across the landscape than are suggested by the map of major settlements and fortifications of the medieval era identified by extensive survey (even if it is likely that the lesser sites are dependent on the major ones). Most of the medieval sites, major and minor nucleations, are abandoned during the 14th century, so that a reconstruction of both the major network of foci and of lesser hamlets has to take place, primarily through the targeted recolonisation of incoming Albanian settlers into deserted village locales. By the late 16 th century however (the Early Ottoman era), the success of this process, taken together with the expansion of Greek refuge villages, provides a Boeotian landscape with many more villages and hamlets than today (Fig. 16). Once again, a century of crisis - the $17 \mathrm{th}$, and subsequent recurrence of economic and security problems, wipes out almost half of these settlements by the end of the 19th century, so that the map of early modern villages is in reality the final result of a process of contraction of a much more numerous network. Interestingly, the pattern of a withdrawal in the 14th century of Greek-speaking populations to a small number of large refuge sites might conceivably provide a model for both the post-Mycenaean and post-Roman Dark Ages.

\section{THE SLAV-ARVANITIC IMMIGRATIONS, SETTLEMENT SHIFTS, AND ARCHAEOLOGY}

Our discussion of ethnic continuity and discontinuity has raised important questions about the interpretation of material culture. Many have hoped to use the occurrence of 'Slav Ware' to trace the historicallydocumented arrival of Slav populations across
Mainland Greece during the transition from the late Roman to Early Byzantine eras. In reality the findspots and quantity of such ceramics make them too exotic to be a likely indicator in most of Greece, and it is more likely that the pottery which was in use through the post-Roman Dark Ages (c. AD 600-900) in the Greek provinces was some kind of derivative Late Roman ware, whether its users were GrecoRoman, Slav, or mixed populations. As for the later Albanian (Arvanitic) immigration (commencing in the final 14th century), the material culture signals are again unlikely to be helpful. Despite the fact that the language remains even today a distinctive trait for Arvanitic villages of Southern Greece, we know that aspects of Arvanitic dress were adopted by rural 'Greeks' too. What of other areas of material culture?

Our recent work on domestic buildings in deserted village sites and contemporary villages and towns has begun to shed some light on the question of ethnic house-types in Boeotia (Stedman 1996; Bintliff et al. 1999). Rural long-houses are likely to be a shared form between the two contemporary ethnic communities of post-medieval Boeotia - Greeks and Arvanites (immigrants of Albanian origin), whilst ceramics seem the same from village to village across the entire medieval-post-medieval era.

Are there perhaps micro-locational shifts in settlements across the immigration boundaries? The known villages with Slav names seem to be immediately over ancient sites, leaving us to try and tease apart the alternative models of a GrecoRoman/Slav merger or replacement, but the Arvanitic policy of settling very close but not usually directly over an abandoned settlement is already notable in the handful of local case-studies our Project has investigated (for example at Archonditsa, Kakosi, Zogra Kobili in South-East and South-Central Boeotia and at Gjin Vendre in Northern Boeotia). On the other hand, we have also, earlier in this paper, been able to point to cases of village relocations to adjacent sites where a significant degree of population continuity is very likely or almost certain (for example with ancient Askra/medieval VM4/post-medieval Panagia/modern Palaiopanagia, ancient Thespiai/ medieval Erimokastro/modern Thespiai and medieval Harmena to post-medieval Mavrommati Harmena to modern Mavrommati), so that no general rule is possible. 


\section{SETTLEMENT THEORY}

The analysis of Boeotian settlement over a very long timescale seems to be providing increasing evidence for two complementary tendencies:

A. The recurrent stabilisation of a network of nucleated hamlet-village settlements at around $2-3 \mathrm{~km}$ radius of territory across the cultivable zones of the province (conforming to the prediction made by John Fossey for Boeotia in 1988 and also in agreement with my own Boeotian work (Bintliff 1994) and further crosscultural studies (cf Bintliff 1999)). In most periods from the Early Bronze Age onwards some of these villages may grow into regional central places and, in the most flourishing periods, many villages reach urban status. Not discussed here is the evidence from Boeotia that top-level regional centres in Greco-Roman and Early Modern times may well exhibit a spacing predicted by rural marketing theory - ie, a day-return radius of 15 $\mathrm{km}$ (comparable to Fossey's empirical estimate of $14 \mathrm{~km})$.

B. Below this network a vastly more numerous interstitial infill of lesser hamlets, farms, and villas rises and falls, period by period, generally indicative of the growth or contraction of population and economy, or the impact of specific forms of land-use (eg, the advent of plough agriculture and the Secondary Products revolution in Final Neolithic-Early Helladic times).

\section{CONCLUSION}

It seems at the present time, from the empirical analysis outlined in this paper, that the reasons for the continuity or reinvention of the standard network of nucleated sites rest more on geography than historical continuity or ethnic stability. This conclusion harmonises excellently with the reading of Greek landscapes achieved by the German Landeskunde (Landscape-Lore) school of historical geography between the final decades of the 19th century and the 1950s (and sadly-neglected by subsequent scholarship). A particularly relevant application is Lehmann's analysis of the long-term settlement history of the micro-regions of Crete (Lehmann 1939), where the concept of the Siedlungskammer was deployed to stimulating effect: 'settlement chambers' are identified in the landscape, areas within which there is usually a single major settlement at any one period, but its precise location is a conjunction of natural geographic opportunities and the specific economic and political context of the culture concerned. The persistence of the 'parish' as an area of recurrent settlement, overrides major alterations in ethnic group or political structure, whilst the minor displacements of the chief settlement or its apparent stability can easily be confused with continuity of population. The same approach has been developed further, in recent years, by contemporary Czech prehistorians as the 'Community Area' model (Kuna 1991).

As a warning against taking to extremes a currently-fashionable trend in landscape archaeology theory (cf. Barrett 1994; Bender et al. 1997; Tilley 1994), the regional case-study evidence from Boeotia presented in this paper furthers the argument that the distribution of fertile agricultural land, ergonomic work constraints on territorial size, social factors affecting the dispersion of communal groups, and limited locational possibilities for settlement microlocation, appear more important than the conscious inheritance of traditional 'senses of place', or continuity of populations and cultures. As an alternative to the current preoccupation with cultural aesthetics and emotional behaviourism, these considerations could lead us more profitably towards recent developments in scientific thinking, in particular Complexity Theory, where potentially highly variable and historically very specific agglomerations of elements show recurrent tendencies towards systematic patterning of a complex form, as the result of the operation of factors which are 'enabling and constraining' (the 'strange attractors' which produce order out of chaos) (Bintliff 1997b; Lewin 1993).

\section{BIBLIOGRAPHY}

Alcock, S.E. 1993. Graecia Capta. The Landscapes of Roman Greece. Cambridge: University Press

Alcock, S.E. 1997. Changes on the ground in Early Imperial Boeotia. In J.L. Bintliff (ed.), Recent Developments in the History and Archaeology of Central Greece, 287-304. Oxford: British Archaeological Report $\$ 666$

Andel, T. H. van \& Runnels, C.N. 1995. The earliest farmers in Europe. Antiquity 69, 481-500 


\section{J. Bintcliff et al. DECONSTRUCTING 'THE SENSE OF PLACE'? SETTLEMENT, FIELD SURVEY, HIST REC: CENT GREECE}

Barrett, J.C. 1994. Fragments from Antiquity. Oxford: Blackwell

Bender, B., Hamilton, S.C., Tilley, C. 1997. Leskernick: stone worlds; alternative narratives; ovested landscapes. Proceedings of the Prehistoric Society 63, 147-78

Bintliff, J.L. 1991. The Roman countryside in Central Greece: observations and theories from the Boeotia Survey (1978-1987). In G. Barker, \& J. Lloyd (eds), Roman Landscapes. Archaeological Survey in the Mediterranean Region, 122-32. London: British School at Rome

Bintliff, J.L. 1992. The Boeotia Project 1991: survey at the city of Hyettos. In P. Lowther (ed.), University of Durham and University of Newcastle upon Tyne Archaeological Reports, 23-8. Durham: University

Bintliff, J.L. 1994. Territorial behaviour and the natural history of the Greek polis. In E. Olshausen \& $\mathrm{H}$. Sonnabend (eds), Stuttgarter Kolloquium zur Historischen Geographie des Altertums 4, 207-49, Pls 19-73. Amsterdam: Hakkert Verlag

Bintliff, J.L. 1995. The two transitions: current research on the origins of the traditional village in central Greece. In J.L. Bintliff, \& H. Hamerow (eds), Europe Between Late Antiquity and the Middle Ages. Recent Archaeological and Historical Research in Western and Southern Europe, 111-30. Oxford: British Archaeological Report S617

Bintliff, J.L. 1996. The Frankish countryside in central Greece: The evidence from archaeological field survey. In P. Lock \& G.D.R. Sanders (eds), The Archaeology of Medieval Greece, 1-18. Oxford: Oxbow

Bintliff, J.L. 1997a. The archaeological investigation of deserted medieval villages in Greece. In G. D. Boe \& F. Verhaege (eds), Rural Settlements in Medieval Europe. Papers of the Medieval Europe Brugge 1997 Conference 6, 21-34. Zellik: Archaeological Institute for the Heritage

Bintliff, J.L. 1997b. Catastrophe, chaos and complexity: the death, decay and rebirth of towns from Antiquity to today. Journal of European Archaeology 5, 67-90

Bintliff, J.L. 1997c. Further considerations on the population of ancient Boeotia. In J.L. Bintliff (ed.), Recent Developments in the History and Archaeology of Central Greece, 231-52. Oxford: British Archaeological Report S666

Bintliff, J.L. 1999. Settlement and territory. In G. Barker (ed.), Companion Encyclopedia of Archaeology, 505-45. London: Routledge

Bintliff, J.L., Aalen, F., Sigalos, E. \& Spoerry, P. 1999. The traditional vernacular architecture of Livadhia. In Livadhia: Past, Present and Future, 85-103. Livadhia, Greece: Municipality Publication

Bintliff, J.L. \& Snodgrass, A.M. 1985. The Boeotia survey, a preliminary report: The first four years. Journal of Field Archaeology 12, 123-61

Bintliff, J.L. \& Snodgrass, A.M. 1988a. Mediterranean survey and the city. Antiquity 62, 57-71

Bintliff, J.L., \& Snodgrass, A.M. 1988b. Off-site pottery distributions: A regional and interregional perspective. Current Anthropology 29, 506-13

Bintliff, J.L. \& Snodgrass, A.M. 1989. From polis to chorion in South-West Boeotia. In H.Beister \& J.Buckler (eds), Boitika. Vorträge vom 5. Internat. BoötienKolloquium, 285-99. Munich: Editio Maris

Etienne, R. \& Knoepfler, D. 1976. Hyettos de Béotie et la Chronologie des Archontes Fédéraux. Paris: Editions de Boccard

Fossey, J.M. 1988. Topography and Population of Ancient Boeotia. Chicago: Ares Publishers

Johnson, M. 1996. Water, animals and agricultural techology: A study of settlement patterns and economic change in Neolithic Southern Greece. Oxford Journal of Archaeology 15, 267-95

Kiel, M. 1997. The rise and decline of Turkish Boeotia, 15th-19th century. In J.L. Bintliff (ed.), Recent Developments in the History and Archaeology of Central Greece, 315-58. Oxford: British Archaeological Report S666

Kirsten, E. 1956. Die Griechische Polis als historisch-geographisches Problem des Mittelmeerraumes. Bonn: Colloquium Geographicum 5

Koder, J. \& Hild, F. 1976. Hellas und Thessalia. Wien: Osterreichische Akademie der Wissenschaften

Kuna, M. 1991. The structuring of prehistoric landscape. Antiquity 65, 332-47

Kuna, M. in press. Surface artefact studies in the Czech Republic. In J. Bintliff, M. Kuna \& N. Venclova (eds), The Future of Archaeological Field Survey in Europe. Sheffield: Sheffield Academic Press

Lehmann, H. 1939. Die Siedlungsräume Ostkretas. Geographische Zeitschrift 45, 212-28

Lewin, R. 1993. Complexity. Life at the Edge of Chaos. London: Dent

Lock, P. 1995. The Franks in the Aegean, 1204-1500. London: Longman

Osborne, R. 1996. Greece in the Making, 1200-479. London: Routledge

Salac, V. 1995. The density of archaeological finds in settlement features of the La Tène period. In M. Kuna \& N. Venclova (ed.), Whither Archaeology? Papers in Honour of Evzen Neustupny, 264-76. Praha: Institute of Archaeology, Prague

Sherratt, A. 1981. Plough and pastoralism: aspects of the secondary products revolution. In I. Hodder, G. Isaac \& N. Hammond (eds), Pattern of the Past. Studies in Honour of David Clarke, 261-305. Cambridge: University Press

Snodgrass, A.M. 1980. Archaic Greece: The Age of Experiment. London: Dent

Stedman, N. 1996. Land-use and settlement in postmedieval central Greece: an interim discussion. In P. Lock \& G.D.R. Sanders (eds), The Archaeology of Medieval Greece, 179-92. Oxford: Oxbow

Tilley, C. 1994. A Phenomenology of Landscape. Oxford: Berg

Vroom, J. 1997. Pots and pans: new perspectives on medieval ceramics in Greece. In G. de Boe \& F. Verhaeghe (eds), Material Culture in Medieval Europe. Papers of the Medieval Europe Brugge 1997 Conference 7, 203-13. Zellik: Archaeological Institute for the Heritage 